\title{
Capital Structure Policies In Europe:
}

\section{SURVEY EVIDENCE}

\section{Dirk Brounen, Abe de Jong and Kees Koedijk}

\begin{tabular}{|l|l|}
\hline \multicolumn{2}{|l|}{ ERIM REPORT SERIES RESEARCH IN MANAGEMENT } \\
\hline ERIM Report Series reference number & ERS-2005-005-F\&A \\
\hline Publication & February 2005 \\
\hline Number of pages & 35 \\
\hline Email address corresponding author & ckoedijk@rsm.nl \\
\hline Address & Erasmus Research Institute of Management (ERIM) \\
& RSM Erasmus University / Rotterdam School of Economics \\
& Erasmus Universiteit Rotterdam \\
& P.O. Box 1738 \\
& 3000 DR Rotterdam, The Netherlands \\
& Phone: + 31104081182 \\
& Fax: $\quad+31104089640$ \\
& Email: info@erim.eur.nl \\
& Internet: $\quad$ www.erim.eur.nl \\
\hline
\end{tabular}

Bibliographic data and classifications of all the ERIM reports are also available on the ERIM website: www.erim.eur.nl 


\section{ERASMUS RESEARCH INSTITUTE OF MANAGEMENT}

\section{REPORT SERIES}

\section{RESEARCH IN MANAGEMENT}

\begin{tabular}{|c|c|c|}
\hline \multicolumn{3}{|c|}{ BIBLIOGRAPHIC DATA AND CLASSIFICATIONS } \\
\hline Abstract & \multicolumn{2}{|c|}{$\begin{array}{l}\text { In this paper we present the results of an international survey among } 313 \text { CFOs on capital } \\
\text { structure choice. We document several interesting insights on how theoretical concepts are } \\
\text { being applied by professionals in the U.K., the Netherlands, Germany, and France and we } \\
\text { directly compare our results with previous findings from the U.S. Our results emphasize the } \\
\text { presence of pecking-order behavior. At the same time this behavior is not driven by asymmetric } \\
\text { information considerations. The static trade-off theory is confirmed by the importance of a target } \\
\text { debt ratio in general, but also specifically by tax effects and bankruptcy costs. Overall, we find } \\
\text { remarkably low disparities across countries, despite the presence of significant institutional } \\
\text { differences. We find that private firms differ in many respects from publicly listed firms, e.g. listed } \\
\text { firms use their stock price for the timing of new issues. Finally, we do not find substantial } \\
\text { evidence that agency problems are important in capital structure choice. }\end{array}$} \\
\hline \multirow{3}{*}{$\begin{array}{l}\text { Library of Congress } \\
\text { Classification } \\
\text { (LCC) } \\
\text { LCC Webpage }\end{array}$} & \multicolumn{2}{|c|}{ Mission: HF 5001-6182 } \\
\hline & \multicolumn{2}{|c|}{ Programme: HF 4001-4280.7 } \\
\hline & Paper: & HG 4001 Financial management \\
\hline \multirow{3}{*}{$\begin{array}{l}\text { Journal of Economic } \\
\text { Literature } \\
\text { (JEL) } \\
\text { JEL Webpage }\end{array}$} & \multicolumn{2}{|l|}{ Mission: M } \\
\hline & \multicolumn{2}{|l|}{ Programme : $\mathrm{G} 3$} \\
\hline & Paper: & $\begin{array}{l}\text { G32 Financing Policy; Capital and } \\
\text { Ownership Structure }\end{array}$ \\
\hline \multicolumn{3}{|c|}{ Gemeenschappelijke Onderwerpsontsluiting (GOO) } \\
\hline \multirow[t]{3}{*}{ Classification GOO } & \multicolumn{2}{|l|}{ Mission: 85.00} \\
\hline & \multicolumn{2}{|l|}{ Programme: 85.30} \\
\hline & Paper: & 85.30 Financieel management \\
\hline \multirow[t]{3}{*}{ Keywords GOO } & \multicolumn{2}{|c|}{ Mission: Bedrijfskunde / Bedrijfseconomie } \\
\hline & \multicolumn{2}{|c|}{ Programme: Financieel management, besliskunde } \\
\hline & \multicolumn{2}{|c|}{ Paper: investeringen, financiële positie, aandelen } \\
\hline Free keywords & \multicolumn{2}{|c|}{ International economics, financial economics, capital structure, debt maturity, equity issues } \\
\hline
\end{tabular}




\title{
Capital Structure Policies in Europe: SURVEY EVIDENCE
}

\author{
Dirk Brounen \\ Rotterdam School of Management \\ Erasmus University Rotterdam \\ Abe de Jong \\ Rotterdam School of Management \\ Erasmus University Rotterdam \\ Kees Koedijk \\ Rotterdam School of Management \\ Erasmus University Rotterdam \\ CEPR
}

Current Draft: February 2005

Keywords: international economics, financial economics, capital structure, debt maturity, equity issues

JEL Classification Numbers: G31, G32

Correspondence to: Kees Koedijk, Erasmus University Rotterdam, Department of Financial Management, P.O. Box 1738, 3000 DR, Rotterdam, The Netherlands, ckoedijk@fbk.eur.nl. We thank two anonymous referees for helpful comments. The authors thank the Vereniging Trustfonds Erasmus Universiteit Rotterdam for their financial support. 


\title{
CAPital STRUCTURe Policies in EUROPE: SURVEY EVIDENCE
}

\begin{abstract}
In this paper we present the results of an international survey among 313 CFOs on capital structure choice. We document several interesting insights on how theoretical concepts are being applied by professionals in the U.K., the Netherlands, Germany, and France and we directly compare our results with previous findings from the U.S. Our results emphasize the presence of peckingorder behavior. At the same time this behavior is not driven by asymmetric information considerations. The static trade-off theory is confirmed by the importance of a target debt ratio in general, but also specifically by tax effects and bankruptcy costs. Overall, we find remarkably low disparities across countries, despite the presence of significant institutional differences. We find that private firms differ in many respects from publicly listed firms, e.g. listed firms use their stock price for the timing of new issues. Finally, we do not find substantial evidence that agency problems are important in capital structure choice.
\end{abstract}




\section{Introduction}

Capital structure policy deals with the financing of firm's activities, with debt, equity and intermediate securities. Since Modigliani and Miller $(1958,1963)$ a theoretical framework has been developed in which contributions that aim to explain the capital structure decisions of financial managers are embedded. Within this theoretical framework the static trade-off theories of tax benefits, bankruptcy costs and agency problems are well-established. More recently, the pecking-order theory has been added as a description of capital structure choice. After Modigliani and Miller concluded irrelevance under stringent assumptions, subsequent work has added many potential explanations for capital structure policies in firms.

While the development of theory has evolved rapidly, empirical research lagged behind. For example Rajan and Zingales (1995) raise the question: What do we know about capital structure? Unfortunately we have to conclude, from this and many other empirical papers, that we understand only part of the practice of capital structure choice. This study aims to add to the empirical literature by providing survey evidence on capital structure choice in firms in four large European economies. For the U.K., the Netherlands, France and Germany we describe in great detail the relevance of factors driving capital structure choice.

A recent strand of empirical literature has applied the survey instrument to rigorously confront practioners' views with theory. The most famous study in this field is Graham and Harvey (2001). In their study the authors analyze the practice of corporate finance within a sample of 392 U.S. CFOs, by focusing on the relevance of important theoretical factors in capital structure choice, as well as in cost of capital estimations and capital budgeting. In a subsequent study Bancel and Mittoo (2004) examine capital structure policies of 87 CFOs from 16 different European countries. Due to the limited sample size, these authors do not present country-specific results and whereas Graham and Harvey surveyed both publicly listed and private firms, Bancel and Mittoo's sample exclusively consists of public firms. The added value of our survey is that we present results for a sample of 313 CFOs from four European countries. We have both public and private firms in our sample and we have a sufficient number of observations per country, which allows us to describe the determinants of capital structure policies in each of the four nations and to investigate the impact of a public listing. Our setup is similar to Graham and Harvey's U.S. approach and thereby we can directly test whether their conclusions are also valid outside the U.S. We pay particularly attention to differences between CEOs of private firms versus their collegues in publicly listed firms. 
Overall, our results show some intriguing patterns in capital structure choices. We document remarkably low disparities between corporate debt policies across countries. Respondents in all four national samples report financial flexibility to be the key factor when determining their debt structure, a result which corroborates previous studies from the U.S. and the 16-country European sample. However, the importance of flexibility is not driven by the pecking-order theory. In line with Graham and Harvey (2001) we find evidence which moderately supports the static trade-off theory in each of the four countries. At the same time we find no convincing evidence in the full sample for agency problems, signaling, or a role of capital structure in control contests in either country. This is a striking result, because the theoretical and empirical literature largely focuses on these issues. The findings are also surprising in comparison with earlier results by Bancel and Mittoo (2004), who find signaling and agency problems to be important factors in capital structure choice. Finally, we find that the influence of a quotation at a stock exchange induces several factors to be only relevant for these public firms. Public firms tend to time new issues on the basis of their stock price. Also, public firms consider debt relevant to become an unattractive takeover target, while these control contests are not relevant in private firms. Finally, in comparison with private firms, listed firms are more inclined to signal their prospects to financial markets by increased debt levels.

The paper is organized as follows. In the next section, we present the survey procedures. In section 3 we describe the firm's sample statistics. Section 4 tests static trade-off theories and section 5 focuses on asymmetric information-based theories, such as the pecking-order theory. Section 6 investigates the practical relevance of agency theory in capital structure and section 7 describes miscellaneous issues. Section 8 concludes.

\section{Data and methodology}

Our survey questions exactly match Graham and Harvey’s (2001) inquiries on capital structure policy, which facilitates a direct comparison of our results. Bancel and Mittoo (2004) also address these questions in their study. In addition, we posed questions about cost of capital estimations and capital budgeting; the results for these questions are described in Brounen, De Jong and Koedijk (2004).

From the Amadeus dataset of Bureau Van Dijk we selected all firms with a staff of a least 25 employees. We also collected data on sales, industry and public listing. Next, we use the Kompass database with names and positions of the high-ranked officials and collect the names of the CFO for each firm in the Amadeus data set. First, we select all public firms in each country. We complement our sample sets with 
randomly chosen private firms of which the name of the CFO is disclosed. Our final set contains 2000 firms in the U.K., Germany and France, and 500 firms in the Netherlands.

The text of the survey of Graham and Harvey (2001) has been translated into German and French by a certified translation agency and into Dutch by the authors. We conducted trial sessions with CFOs in each of the four countries to test whether the translations were correct and understandable. We adjusted the wording and added brief explanations, based on the CFO's feedback. In these sessions the average time to fill out the questionnaire was around 15 minutes. In the period of November 1 to 8, 2002 the questionnaires were sent by mail to the sample firms. The questionnaire was sent out by a third party, in order to ensure that the results are handled anonymously, expecting that this stimulates respondents to answer frankly. Each firm received a cover letter, the four-page questionnaire, a pre-stamped envelope and a response form to request a free report of the results. The latter serves as an incentive to fill in the questionnaire. The respondents were offered the opportunity to return their questionnaire by mail or by fax. Two weeks after the firms had received the questionnaire all non-respondents were contacted by phone by native speakers, reminding them to return the questionnaire. During the phone conversation, the respondents could go through the questions over the phone immediately or receive by email a link to a web page for filling in the questionnaire. This telephonic and email effort lasted until January 7, 2003 and we received our last response on January 30, 2003.

In total, we received 313 responses, 68 in the U.K., 52 in the Netherlands, 132 in Germany and 61 in France. We received $50.5 \%$ of the questionnaires by mail or fax, $19.2 \%$ by telephonic interviews and 30.3\% through the web page. We analysed our results with regard to potential response biases, which are a common threat to survey research. ${ }^{1,2}$ Overall, we find that our sample is representative of the overall universe of firms and we detect only a small variation in answers based on the response technique.

\footnotetext{
${ }^{1}$ We investigate whether the returned questionnaires contain a bias, caused by the type of response medium or by the sequence of questions. First, we cluster our results along the way in which the responses have been received (mail, fax, telephone or internet) and analyse both the average responses and the distributions within each cluster. In total we have 68 items and 4 response clusters. Using a standard mean-test for all 6 comparisons between the 4 clusters we find 14 differences significant at the $10 \%$ level. This implies that the results are not biased, because for a random set we expect 41 significant differences (10\% of 68 times 6 ). At the $5 \%$ level we find 9 differences and expected 20 . We found no distinct patterns in the differences between clusters. For our second test we sent out two versions, with questions 1-4 and 11-14 interchanged. We find at the 10\% significance level 2 differences between the two sets, while a random set would yield 8 differences (10\% of 68 ). At the $5 \%$ level we find 1 difference and expected 4. Thus, we detect no significant differences in responses based on the questionnaire structure.

${ }^{2}$ We performed an experiment in order to investigate whether our results are affected by non-response bias. We follow the example of Moore and Reichert (1983) by comparing characteristics firm size, industry, and public status of the responding firms to the non-respondents. We find no statistically significant differences between the two groups on a $5 \%$ confidence level and therefore we may consider our sample to be representing the population.
} 
The overall response rate is $5 \%$, which is somewhat lower than studies like Trahan and Gitman (1995) and Graham and Harvey (2001), which obtained a 12\% and 9\% response rate respectively. However, given the length and depth of our questionnaire and the vast size of our sample we feel confident when analysing our results.

Our questionnaire includes questions about firm characteristics and about the CFOs' views on factors related to capital structure choice. The general firm characteristics are size (sales), industry, publicly listed/private, regulated and dividend policy. We also ask for characteristics specifically related to capital structure: the debt ratio, presence of a target ratio, and whether the firm considered the issuance of equity, convertible debt and foreign debt. The remaining questions measure the CFOs' views on the factors related to capital structure choice on a scale from 0 (not important) to 4 (very important). In our analysis we also include Bancel and Mittoo's (2004) results for the 87 firms from 16 European countries and Graham and Harvey’s (2001) data for 393 U.S. firms. ${ }^{3}$ Our analysis starts with the description of our sample by the firm characteristics in Table 1 . Tables 2 and 3 contain average scores per country for the importance of capital structure factors, for the full sample and for sub-samples based on leverage or target ratio. In capital structure, leverage and target ratio are the most relevant determinants. Comparisons of sub-samples based on multiple criteria are limited, due to the number of observations per sub-sample. Therefore, in Tables 4 and 5 we describe ordered logit regressions, which simultaneously measure the impact of several firm characteristics on capital structure choice. The regression tests require an ordered logit regression technique, because of the ordinal 5-point Likert scales we apply (see Peterson and Harrell, 1990). In Tables 4 and 5 we select factors from respectively Tables 2 and 3 and explain their importance by country dummies and a dummy for private firms. Because we are particularly interested in the effect of a public listing, we also include interaction terms for leverage, target ratio, size and dividend, with a dummy for public firms and a dummy for private firms. In Tables 6, 7 and 8 we describe average scores per country, specifically for firms which indicated the consideration of foreign debt, equity and convertible debt issues. Finally, Table 9 investigates the relevance of factors in debt maturity per country and for sub-samples based on leverage or target ratio.

\footnotetext{
${ }^{3}$ Graham and Harvey (2003) provide a description of the data in Graham and Harvey (2001), including a reference to the data which is publicly available on a web page. We are grateful to the authors for the availability of their data, which allows us to incorporate the U.S. data in our study in addition to our sample of European firms.
} 


\section{Description of the sample}

The sample of responding firms is described in Table 1. The first four columns describe the firms in the U.K., the Netherlands, Germany and France. In the fifth column we include Bancel and Mittoo’s (2004) data set of 87 firms from 16 European countries. The sixth column contains the Graham and Harvey (2001) data for 393 U.S. firms.

\section{[Please insert Table 1 here]}

The sales data provide an overview of the size distribution in the samples. The sample distribution within our four European samples shows a distinct resemblance regarding this size proxy, given the large proportion in the groups with sales below $€ 500$ million. It should be noted that the U.K. and France have relatively more firms in the smallest size group. The differences with the Bancel and Mittoo data are striking. More than $80 \%$ of their observations belong to the group with sales over $€ 1$ billion. This distinct sample difference is a direct result of the underlying sample selection procedures. Bancel and Mittoo's Pan-European sample is comprised of all non-French firms with daily trading information in La Tribune, complemented with French firms in the SBF 120 index. As a result of the procedure and as evidenced by the sales data, the sample contains relatively large firms. In comparison with the U.S. data, our samples are slightly under-represented in the two largest groups. While $51 \%$ of all firms in their U.S. sample have sales exceeding $€ 500$ million, this number is less than $25 \%$ in each of our European samples.

The distribution across industry types is rather similar in all countries, with most firms belonging to manufacturing in each sample. Like Graham and Harvey we document that non-manufacturing firms are spread evenly across other industries in our European samples. The Bancel and Mittoo data has relatively few firms in the manufacturing industry, while the financial section is over-represented.

As a result of the sample selection procedure all Bancel and Mittoo's firms are publicly listed. In the U.K. and U.S. more than half of the sample consists of exchangelisted firms, while in the other countries the fractions are lower. For the fraction of regulated utilities we find that in France these firms are more present than in the other countries. Dividend-payers are present in all countries' samples for over $50 \%$. Regarding corporate debt policy, we find that about a quarter of the firms in the U.K. and France have no long-term debt at all. These firms are financed completely with equity and short-term liabilities. The German firms are over-represented in the 10-19\% interval, while many Dutch firms are in the 20-29\% interval. Subsequently, we define low-levered firms as firms with leverage below 30\%, while highly levered firms have a 
debt ratio above $30 \%$. The fractions of firms with low and high leverage are hardly different between the countries. The only exception is France, which is underrepresented in the highest interval. This international pattern in leverage complies with previous studies of Rajan and Zingales (1995) and De Bondt (1998), which document similar national differences and explain them by emphasizing institutional differences.

\section{Trade-off theory of capital structure choice}

The static trade-off theory predicts a trade-off between tax advantages and bankruptcy costs of debt. According to this theory, firms balance beneficial tax shields with the financial distress costs when determining the appropriate amount of corporate debt. Firms that act along the lines of the static trade-off paradigm are expected to have a target debt ratio.

[Please insert Figure 1 here]

Figure 1 shows that in the U.K., the Netherlands and Germany over two-thirds of firms aim for some target debt ratio. Of the French firms in our sample less than a third has a target ratio. A second striking result is that in each of the countries merely $10 \%$ of all firms maintain a strict target. Although the target ratio is evidence in favor of the static trade-off theory, the theory also prescribes specific determinants of this target debt ratio. We further test the trade-off theory by inquiring about the importance of several determinants. In Tables 2 and 3 we describe the responses.

[Please insert Tables 2 and 3 here]

The two prevailing determinants of leverage in the static theory are tax benefits and bankruptcy costs. We find that tax advantages of interest expenses are considered to be the fourth most important factor when considering the proper amount of debt (see row (a)), after financial flexibility, credit ratings and earnings volatility. The cross-national variation in this result is modest and indicates that tax advantages are considered to be of equal importance to European and U.S. firms, which the only exception that German CFOs attach lower importance to tax influences. An interesting discovery in Table 2 is that firms with higher leverage and a target debt ratio are more likely to consider tax advantages of debt an important factor. In Table 4 we further investigate the relevance of tax effects.

[Please insert Tables 4 and 5 here] 
The ordered logit regression in row (a) of Table 4 confirms that German firms consider tax effects significantly less important. This is a striking result, because La Porta et al. (2000) describe corporate tax rates in our countries and the German rate is highest (54\%), in comparison with the other countries (between $33 \%$ and 42\%). The insignificant coefficient for private firms (Private) indicates that the listed firms do not consider taxation more or less important. The significantly positive coefficients for the interaction term of Public and Size (effect of size in public firms) and the interaction term of Private and Size (effect of size in private firms) show that taxation is more important for larger firms, irrespective of the public/private status. The private firms with a target ratio and public firms that pay dividends consider taxes to be relatively important.

Desai (1998) concludes that foreign debt is issued in response to tax advantages in the foreign country. A sub-sample of firms has considered issuing debt in foreign countries. In Table 6 we report the responses of these firms. We report the average national response in row (a) of Table 6, which yields comparable results ranging between 1.0 for France and 2.27 for the U.K. All in all, the outcomes indicate that tax shield advantages are taken in into account by European firms, and overall the importance is comparable those reported previously for U.S. studies.

\section{[Please insert Table 6 here]}

The negative effects of debt financing, i.e. bankruptcy costs, appear to be considered less important judging by the results in Table 2, row (b). On a scale of 0 to 4, costs of bankruptcy scores range only between 0.65 for France and 1.42 for the Netherlands. Bankruptcy costs are most relevant in firms with volatile earnings and cash flows (Table 2, row (h)). We find that volatility is an important determinant in all countries, emphasizing the importance of bankruptcy effects. Again, we find no compelling variation across countries or continents for the two questions discussed above. This is surprising, because bankruptcy costs depend of a country's bankruptcy system. Pochet (2002) describes the insolvency codes in five countries and considers the German, French and U.S. systems debtor-oriented, because debtors are temporarily protected to aim to maintain the business as a going concern. In the U.K. (Pochet, 2002) and the Netherlands (Couwenberg, 2001) creditor-oriented systems prevail, which are harsh on defaulting firms. Based on these institutional differences we would expect bankruptcy effects to be more pronounced in the U.K. and the Netherlands. Instead, we find strong similarities across countries, with one exception. In line with the debtor-orientation in the German system, this country scores relatively low in rows (b) and (h). We do find that firms with high leverage seem more concerned about these costs, which is an 
obvious result because their expected bankruptcy costs are larger. From Table 4, row (h), we conclude that the public status of a firm does not influence the importance of volatility. As expected, since bankruptcy costs are part of the static trade-off theory, we find that both public and private firms with a target ratio consider volatility more important. In all countries we find that firms consider bankruptcy costs to be of lesser importance than tax advantages.

Finally, personal tax effects may offset or increase the tax advantage of debt and thereby impact the optimal balance between corporate tax effects and bankruptcy costs. The low scores in row (f) of Table 2 clearly show that, similar to the U.S., our European firms do not put much weight on the personal tax considerations of their investors. Apparently, firms do not try to attract specific investor clienteles through their capital structure choice. ${ }^{4}$ However, Table 4 indicates that public firms consider personal taxes significantly more important than private firms.

Welch (2004) argues that stock returns affect market value debt ratios, because the value of equity changes. Thus, in case firms express their target debt ratios in market values, they will have to rebalance after changes in equity value. We test this hypothesis and the results in row (g) of Table 3 indicate that the scores are indeed much higher in market-oriented countries. The U.S. and U.K. scores of 1.08 and 0.82 , respectively, well exceed the other countries. A plausible explanation for this international variation is that the firms in the latter countries are less likely to be exchange-listed. The European sample of Bancel and Mittoo has the highest score, which is driven by the fact that all respondent's firms are exchange-listed and thus have market values readily available. This conclusion can also be drawn from Table 5 , where the response to question (g) is significantly lower for private firms at the $1 \%$ significance level. Interestingly, in the sub-sample of public firms we find a positive effect for firms with a target and a negative effect for dividend-payers.

Fisher, Heinkel and Zechner (1989) argue that transaction costs prevent firms from frequently rebalancing their capital structure. Whether transactions costs and fees are important in capital structure choice is shown in Table 2, row (e). This transaction costs hypothesis receives moderate support, with scores ranging between 1.26 for the Netherlands and 1.75 for the U.K. The U.S. and the Bancel and Mittoo samples score higher, respectively 1.95 and 1.94. In row (e) of Table 4, it is shown that this factor is less important in private firms, but the coefficient is not significant at the $10 \%$ level. We also ask firms whether they delay the issuance of debt because of transactions costs and fees, but the low values, which are stated in row (e) of Table 3, yield little support for

\footnotetext{
${ }^{4}$ Based on Miller (1977), Rajan and Zingales (1995, p.1441) tabulate tax effects for several types of investors, for G-7 countries. The tax structures differ across countries, which is not reflected in country differences in our results.
} 
this notion. Apparently transaction costs do not serve as a key driver of corporate debt policy. The subset of firms with a target debt ratios scores significantly higher in several countries in these two questions. The results in Table 5 show that this factor is significantly more important in public firms.

\section{Asymmetric information explanations of capital structure}

In the theoretical corporate finance literature asymmetric information problems have received wide-spread attention. These theories start from the premise that inside managers are better informed than outside investors. As a result, financing decisions inform outsiders about the information insiders have. Based solely on public information, these theories are difficult to test.

\section{Pecking-order model of financing hierarchy}

The pecking-order model of Myers and Majluf (1984) hypothesizes a hierarchy in financing means. First, firms prefer internal financing. Then, external financing is preferred, where debt is preferred over equity. The degree of asymmetric information determines the relative costs of each financing source. Firms that follow this pecking order do not have a target debt ratio, because the ordering determines their preference regarding the issuance of new capital.

Row (g) of Table 2 demonstrates that financial flexibility is the most important factor that influences the amount of debt in each of the five countries, with scores between 2.59 in the U.S. and 1.84 in France. In the Pan-European sample of Bancel and Mittoo the score is even 3.39. On the one hand, this seems to be evidence in favor of the pecking-order model, since flexibility increases the possibility to choose between different financing alternatives. On the other hand, Opler et al. (1999) show that flexibility may be important for other reasons than the pecking order. Interesting is that in France and the U.K. flexibility is significantly more important in firms with a target debt ratio. This finding contradicts the pecking-order interpretation of this question. A more detailed test of the pecking-order theory is to investigate the relationship between asymmetric information and the desire for flexibility. Graham and Harvey use size and dividends as proxies for information problems, i.e. larger and dividend-paying firms have less asymmetry. Therefore, larger firms and dividend-payers are expected to score lower on flexibility. For the U.S. the inverse is found. Larger firms score (insignificantly) higher and also dividend-payers score higher (significant at the 1\% level). In an untabulated analysis we find the same results in each of the four European 
countries. ${ }^{5}$ The difference between large and small firms is significant (at $10 \%$ level) for the U.K. and - except for Germany - larger than the difference in the U.S. For dividends, again the difference in the U.K. is significantly (1\% level) different from zero and always larger than in the U.S. Our multivariate analysis in Table 4 highlights that financial flexibility is more important in dividend-paying firms. These results corroborate Graham and Harvey's conclusion that financial flexibility is not driven by the pecking-order theory.

Our survey includes several questions related to pecking-order behavior. In row (a) of Table 3 we inquire whether a debt issue is triggered by insufficient recent profits. The results are weak and scattered, ranging between 1.24 for France and 2.30 for Germany. Another test of the pecking order is whether equity issues are influenced by the availability internal funds. We describe the considerations of firm that considered an equity issue in Table 7.

\section{[Please insert Table 7 here]}

The result in Table 7, row (g), which link recent profits to the considering of the issuance of new equity, provide very weak confirmation of a pecking order. Row (l) of this Table 7 shows that the inability of obtaining debt financing is even less important when considering a new equity issue. The amount by which a firm's stock is being undervalued or overvalued appears to be more important when considering an equity offer. Firms that seriously consider issuing common stock rates the importance of the current stock valuation between 1.69 in the Netherlands and 2.69 in the U.S., making it the second most important consideration.

In Table 3, row (d) reports what the score is on debt issues when equity is undervalued. This behavior would be consistent with pecking-order theory. Compared to the 1.56 score in the U.S. our European firms score relatively low. This result nicely illustrates the role of security pricing in public markets, which is much lower in continental Europe. As expected, the tests in Table 5 result in a significantly negative coefficient for private firms. Similarly, Bancel and Mittoo's results show a much higher score, because their sample is entirely composed of large exchange-listed firms.

\footnotetext{
${ }^{5}$ The sub-sample results for Table 2, row (g) are as follows. When comparing the small size firms to the large firms we find the following average responses, respectively 2.54 versus 2.65 (U.S.), 2.02 versus 2.88 (U.K., this difference is significant at a 10\% level), 2.22 versus 2.70 (Netherlands), 2.16 versus 2.23 (Germany) and 1.72/2.50 (France). Regarding the split ups based on dividend policy we report the following average responses for dividend payers and non-dividend payers: 2.73 versus 2.40 (U.S., this difference is significant at a $1 \%$ level), 2.74 versus 1.33 (U.K., this difference is significant at a $1 \%$ level), 2.43 versus 2.00 (Netherlands), 2.36 versus 1.98 (Germany) and 2.03 versus 1.40 (France).
} 
Overall, our results for the pecking-order model confirm Graham and Harvey's conclusions: results are in line with the predictions of the pecking-order theory. However, given the results on information differences, asymmetries do not drive the pecking order.

\section{Recent increases in price of common stock}

In the previous analysis we found that European firms reported equity prices to be rather unimportant when considering debt issues and relatively important when planning an issue of new equity. Besides this relative value of stocks we are also interested in whether the absolute variation in stock prices is influencing the issuance of common stock. The results in row (a) of Table 7 show that recent rises in stock prices favor the issuance of new stock in the U.S. and U.K., while our continental European samples pay less attention to stock prices when considering stock issues. This finding emphasizes the relative importance of public capital markets in the Anglo-Saxon countries.

\section{Signaling private information with debt and equity}

According to signaling models, firms can signal quality to investors using their capital structure decisions (Ross, 1977 and Leland and Pyle, 1977). We expect that higher accounting standards reduce private information and thus the information-value of signalling. La Porta et al. (1998) describe a rating for accounting standards, which ranges from 62 (Germany) and 64 (Netherlands) to 69 for France and 71 for the U.S. The highest score is for the U.K., 78. Contrary to our expectations, Table 3, row (b) illustrates that this motivation scores low in all countries, between 0.65 in the Netherlands and 1.06 in France, in all samples when relating it to debt policy. Obviously, we expect this factor to be most relevant among listed firms. Indeed, Table 5 yields a significantly negative coefficient for private firms. Moreover, the Bancel and Mittoo sample yield a high score of 1.55 , which can be attributed to the public status of the firms in their sample. Focusing on equity issues, row (h) of Table 7 yields comparable results, indicating that the firms in our sample do not actively signal information on their corporate prospects and value through their capital structure policy.

\section{Private information and convertible stock issuance}

In Table 8 we report the factors of importance in convertible debt issues, for the subsample of firms that consider a convertible debt issue.

[Please insert Table 8 here] 
Following Brennan and Kraus (1987) we investigate whether convertible debt can be used to attract investors who are uncertain about the firm's risks. Table 8, row (h) reveals that this is relevant in the U.S. (2.07), Netherlands (2.33) and Germany (2.40), while U.K. firms (1.00) and French firms (0.67) consider this motive not to be relevant. Stein (1992) derives a model in which convertibles are "back-door" equity, because they avoid the issuance of undervalued equity. According to our results in row (a) of Table 8 this is indeed important when considering convertible debt. In all samples scores are high and range between 2.83 in the Netherlands and 1.50 in France.

\section{Timing interest rates and credit rating}

In the previous section we inquired about timing on the basis of private information within a firm. Managers may also try to time their issues because they expect that economy-wide interest rates may change. Row (c) of Table 3 yields the surprising result that this is the most important factor in U.S. firms, with a score of 2.22. The scores for the European countries tend to be considerably lower with Germany on the high end 1.87, while Dutch firms report only 1.19 on average. In Table 9 we ask firms about factors, which affect their choice between short-term and long-term debt.

\section{[Please insert Table 9 here]}

Rows (a) and (c) of Table 9 report the influence of expected long and short interest rates in this context and again we find slightly lower values for our European firms compared to the U.S. results of Graham and Harvey. Flannery (1986) argues that managers who expect a higher credit rating than their current rating - because they have superior information - will choose short debt, as their rates for long debt will improve. Table 9, row (e) shows that this argument receives only weak support, only a small minority of firms in each sample consider this argument to be relevant. The respondents most likely interpreted credit ratings in a broad way, because in continental Europe rating agencies are less active, in comparison with Anglo-Saxon countries. However, the results for this question are similar.

Finally, we describe whether firms issue foreign debt because foreign rates are more favorable in Table 6, row (e). The scores are much higher in the U.S. (2.19), the Netherlands (2.42) and Germany (2.64), in comparison with the U.K. (1.36) and France (1.38). 


\section{Agency costs}

Since the contribution of Jensen and Meckling (1976), agency problems are at the heart of the capital structure literature. Agency costs are normally considered as part of the static trade-off, based on asymmetric information and disaligned interest problems. In this section we will discuss several specific agency problems. La Porta et al. (1998) describe institutional details for many countries throughout the world concerning the protection of shareholders and creditors. Because these institutions diverge across countries, the potential for agency problems also differs across countries. Therefore, it is interesting to investigate cross-country differences in the importance of agency problems.

The underinvestment problem, as introduced by Myers (1977), is an agency problem between bondholders and shareholders that arises in situations of debt overhang. In firms with good growth opportunities, new projects will not be started if leverage is high. The motivation is that in these situations bondholder will benefit more than shareholders. In Table 2, row (n) we ask our respondents whether they restrict their borrowing such that profits from new projects can be captured fully by shareholders instead of being paid out as interest to bondholders. The low scores in the range of 0.73 for the Netherlands and 1.30 for the U.K. offer little support for this notion. Because the problem is induced by high leverage we expect that the underinvestment problem is more relevant in the high leverage samples. In France we indeed find significantly different scores of 2.17 and 1.13, indicating that underinvestment matters more in highly levered firms. However, for Germany we find the inverse difference, which is also significant at the $10 \%$ level. Myers' (1977) model also implies that this underinvestment problem can be mitigated by short term financing. In row (d) of Table 9 we test this hypothesis and the results are in line with our earlier findings, again scores are consistently below 1.00 .

Asset substitution is another agency problem between shareholders and bondholders, in which shareholders prefer high-risk projects, because they can fully benefit from the upside potential. On the other hand, bondholders have a fixed claim and prefer projects with lower risk. Leland and Toft (1996) model this problem and find short term debt as a solution. Table 9, row (f) reports low scores, well below 1.00, in each of the five countries. Green (1984) has developed a prominent model in which asset substitution is mitigated by convertible debt issues. We report in row (b) of Table 8 that protecting bondholders against unfavorable actions of shareholders and managers is not an important factor in the convertible debt choice, again the results are consistent and are equal or less than 1.00 . 
Overall, we conclude that the results for the five countries are remarkably similar. By constructing an anti-director index La Porta et al. (1998) show that shareholders have a much larger influence in U.S. and U.K. firms. Thus, one would expect shareholder-bondholder problems in countries with high shareholder influence and low creditor rights, i.e. the U.S. In Germany, one would expect the problems to be less relevant. Given these strong institutional differences, it is striking that the theories are not found to be relevant in either of the countries.

Conflicts between managers and equityholders may also influence capital structure choice. Jensen (1986) notices that managers may have incentives to strive for firm growth by adopting negative NPV projects. Moreover, Jensen and Meckling (1976) argue that managers may work less efficiently, because they are merely partial or no owners of the firm. Through its fixed obligations debt is considered to be a disciplining device, which might mitigate these principle-agent problems. However, our results in row (m) of Table 2 imply that the disciplining role of debt is equally unimportant in each of the five countries, where scores never exceed 0.70. In this question a striking result in the Pan-European Bancel and Mittoo sample arises as 50\% (almost) always considers this factor and the score is 2.33. Partially, this result can be attributed to the sample selection, i.e. in the listed firms manager-shareholder problems are more prevalent. Graham and Harvey attribute the low scores in the U.S. result to two reasons: (1) respondents' bias because managers do not want to admit this behavior; and (2) unwillingness of managers to discipline themselves through debt. It is noteworthy that the above-mentioned anti-director index of La Porta et al. (1998) again does not induce cross-country differences.

\section{Other factors in capital structure choice}

\section{Product market and industry factors}

According to Titman (1984), firms limit their amounts of debt, because stakeholders may fear that the firm goes bankrupt. For customers, this causes problems in case of spare parts and warranties, while for suppliers similar problems arise. We find little confirmation in row (i) of Table 2, where scores are low and scattered between 0.96 in the Netherlands and 1.62 in the U.K. In U.K. firms we even find a significant difference between firms with high and low leverage in line with the expectation that this problem is more relevant in case leverage is higher.

The product market competition model of Brander and Lewis (1986) hypothesizes that substantial amounts of debt are a credible threat to rival firms, in that the firm will not reduce production. In each of the five countries, this theory is hardly a relevant factor. The scores in row (k) of Table 2 are clustered well below 0.75 , and the 
percentage of firms that (almost) always consider this factor varies between $0 \%$ and $3.33 \%$.

While the previous results indicate that product market and competitive effects are of minor importance, industries may play an important role. A firm's industry may simply serve as a reference point and firms may base their capital structure choices on the choices of other firms in the industry. We investigate this behavior in general in row (c) of Table 2, and find scores ranging closely between 1.49 for the U.S. and 1.11 for the U.K. We also analyze this industry factor when inquiring about the planning of equity and convertible debt issuances. Row (f) of Table 7 summarizes the equity results which vary between 0.92 for Germany and 1.80 for France. This range is somewhat wider for the convertible results in row (d) of Table 8, where the minimum is 0.60 for Germany and the maximum is 1.67 in the Netherlands. The evidence is consistent over the three questions and over the five countries, as other firms in the industry are moderately important.

\section{Control contests}

Harris and Raviv (1988) argue that firms may try to have enough debt in order to be an unattractive takeover target. Table 2, row (j) reports that this consideration is relatively unimportant, since for all national samples the average scores are below 0.75. Of course, because private firms cannot be taken over by a hostile bidder, we expect this argument to be less relevant among unlisted firms. Table 4 confirms this conjecture, because we find that private firms attach significantly less value to this factor.

Stulz (1988) claims that managers may object against an issue of common stock, because this dilutes their private stakes in the company. Row (j) of Table 7 reports that this consideration is most important in the U.S., where the score equals 2.14. In our European sample we also find some mild support for this dilution argument, except for Germany where the score is only 0.83 . We would expect that the Bancel and Mittoo sample scores high on this question because the listed firms can be taken over in a control contest. On the contrary, the score is as low as in the other samples. As we noted in the discussion on agency problems, the similarities in the results are remarkably large, given the pronounced institutional differences between the countries.

\section{Risk management}

Many firms receive part of their revenues in foreign currencies. According to Géczy, Minton, and Schrand (1997) the issuance of debt, denominated in a foreign currency, may provide an efficient hedge against the currency risks created by these foreign revenues. In Table 6, we ask respondents whether they use foreign debt issuances as a natural hedge and whether they strive to match foreign cash inflows and outflows. The 
results to these questions are gathered in rows (c) and (d), respectively. The scores on foreign debt as a natural hedge are rather high, ranging between 3.15 for the U.S. and 1.54 for the Netherlands. A similar question is whether foreign debt is issued to match cash in flows and out flows (row (b)). Again the average response was high equalling 1.88 for our German sample up to 2.67 in the U.S. Only in the Netherlands and Germany interest rates are more important determinants of foreign debt choice.

Another risk management perspective is the matching of debt and asset maturity. In each of the five countries, this turns out to be the most important factor in the debt maturity decision. The scores in row (b) of Table 9 range between 2.60 for the U.S. and 1.68 for France. Apparently, firms match the duration of assets and liabilities such that changes in the interest rates have the lowest impact on a firm's operations.

\section{Practical, cash management considerations}

Row (g) of Table 9 shows that the second most important factor in debt maturity choice is the preference for long term debt in order to reduce refinancing risk. In accordance with Graham and Harvey we find that this factor matters most in highly levered firms, indicating that these worry about having to refinance their debt capital in "bad time" and therefore prefer long term financing.

A practical motivation for issuing stock is that the firms have to provide shares for bonus or stock option plans. We also detect this relevant importance in row (c) of Table 7 where our results cluster around 2.00, except for France where we document only 1.40 .

\section{Other}

Hanka (1998) argues that a high debt ratio may help firms in bargaining with employees for concessions. As row (l) of Table 2 reports, this is the most unimportant factor, as in the five countries; only one German firm almost always considers this aspect. Hovakimian, Opler and Titman (2001) find that U.S. firms with high returns on assets are more likely to issue debt. They reason that more profitable firms become underlevered, relative to their targets, and their financing choices serve to off-set earningsdriven changes. Our findings in row (h) of Table 3 show that this empirical evidence does not return in the managers' opinions, as scores remain well below 0.75 in all samples. Also no difference between firms with and without a target debt ratio arises.

The issuance of common stock influences the earnings per share (EPS), which is an often-reported statistic in newspapers and analyst reports. Economically, the value should be unaffected by changes in this number simply because the denominator changes. However, as row (m) of Table 7 proves, EPS dilution is considered to be very important in the U.S., U.K., and in the Netherlands (with scores equalling 2.84, 2.04, 
and 2.23, respectively). Contrasting to Germany and France, where not a single firm considers this EPS effect. The marked differences between the more stock market oriented countries versus Germany and France emphasize our earlier conclusion about the importance of the stock market orientation.

In row (b) of Table 7 we present the scores on whether firms perceive equity as the least risky source of funds. Our results, which range between 1.42 for Germany and 2.00 for France, give a moderate support for Williamson's (1988) arguments that equity is a cheap form of financing in case low asset-specificity. Row (d) states that only a minority of firms considers stock as the cheapest source of funds.

Convertible debt issues normally include a call or forced-conversion feature, which serves as an option, which can be exercised when valuable. Our results in row (g) of Table 8, reports that managers of U.S. and U.K. firms like this feature, given their average score 2.29 and 3.00. CFOs of Continental European firms express lower appreciation for this call feature.

\section{Conclusions}

In this paper we examine the practice of capital structure in four European countries: the U.K., the Netherlands, Germany and France and compare it to previous results by Graham and Harvey for U.S. firms and Bancel and Mittoo for large European publicly listed firms. The static trade-off theory predicts that firms have a target debt ratio, based on tax and bankruptcy considerations. This theory is moderately supported in each of the four European countries. In the U.S. the stronger evidence is found, both for the existence of targets and for the role of corporate taxes. In the Pan-European sample of Bancel and Mitoo scores on the importance of taxation are higher. Financial flexibility is reported to be the most important factor, when determining the proper amount of corporate debt. At the same time we find that this urge for flexibility is not driven by the pecking-order theory.

Rajan and Zingales (2003) suggest strong differences in the financial markets among the European countries, and also in comparison with the U.S. Because financial markets play an important role in theory, we would expect to find that these differences are reflected in capital structure decisions of individual firms. Our practical findings reflect these institutional differences. For example, in the static trade-off, U.S. and U.K. firms tend rebalance after market value changes. In Bancel and Mittoo's sample rebalancing is important, which is in line with the public status of the firms in their sample. Mispricing of equity is more important in the U.S. and U.K. in debt and equity issues. Because the financial markets consider the EPS measure a relevant yardstick for performance, diluting EPS is an important issue in equity issues in the more capital 
market oriented countries, i.e. the U.S., U.K. and the Netherlands. Our results also show that the German and French firms in our sample are less concerned about pricing in financial markets in the capital structure choices. In a regression analysis we find that publicly listed firms attach more value to the timing new issues. The public firms also consider debt important to become unattractive as a takeover target. These control contests are not relevant in private firms' capital structure choices. Finally, in comparison with private firms, listed firms are more inclined to signal their prospects to financial markets by increased debt levels. Overall, we can conclude that we find evidence that financial markets influence capital structure choice.

The relevance of agency problems and the benefits of signaling in capital structure choice are caused by divergent interests and the ability of shareholders and creditors to monitor each other and the management. Recent studies document strong differences between countries in corporate governance structures (La Porta et al., 1998). However, we do not find convincing evidence of agency problems, signaling, or a role of capital structure in control contests in either country. This is a striking result, because the theoretical and empirical literature largely focuses on these issues. The findings are also surprising in comparison with results by Bancel and Mittoo, who find signaling and agency problems to be important factors in capital structure choice.

We conclude that the static trade-off theory faces moderate confirmation. Financial flexibility is important, but not driven by the pecking-order theory. Several practical considerations are highly relevant. Contrary to the institutional variations we document strong resemblances among the four European countries and also with the U.S. when comparing capital structure policies. 


\section{References}

Bancel, F., Mittoo, U.R., 2004. Cross-country determinants of capital structure choice: a survey of European firms. Financial Management 33, 103-132.

Brander, J.A., Lewis, T.R., 1986. Oligopoly and financial structure: the limited liability effect. American Economic Review 76, 956-970.

Brennan, M.J., Kraus, A., 1987. Efficient financing under asymmetric information. Journal of Finance 42, 1225-1243.

Brounen, D., De Jong, A., Koedijk, C.G., 2004. Corporate finance in Europe: confronting theory with practice. Financial Management 33, 71-101.

Couwenberg, O., 2001. Survival rates in bankruptcy systems: overlooking the evidence. European Journal of Law and Economics 12, 253-273.

De Bondt, G.J., 1998. Financial structure: theories and stylized facts for six EU countries. De Economist 146, 271-301.

Desai, M.A., 1998. A multinational perspective on capital structure choice and internal capital markets. Working paper, Harvard Business School.

Fischer, E.O., Heinkel, R., Zechner, J., 1989. Dynamic capital structure choice: theory and tests. Journal of Finance 44, 19-40.

Flannery, M.J., 1986. Asymmetric information and risky debt maturity choice. Journal of Finance 41, 19-37.

Géczy, C., Minton, B.A., Schrand, C., 1997. Why firms use currency derivatives. Journal of Finance 52, 1323-1354.

Graham, J.R., Harvey, C.R., 2001. The theory and practice of corporate finance: evidence from the field. Journal of Financial Economics 61, 187-243.

Graham, J.R., Harvey, C.R., 2003. The theory and practice of corporate finance: the data. Working paper, Duke University (http://ssrn.com/abstract=395221).

Green, R., 1984. Investment incentives debt and warrants. Journal of Financial Economics 13, 115-136.

Hanka, G., 1998. Debt and the terms of employment. Journal of Financial Economics 48, 245-282.

Harris, M., Raviv, A., 1988. Corporate control contests and capital structure. Journal of Financial Economics 20, 55-86.

Hovakimian, A., T. Opler, Titman, S., 2001. The debt-equity choice. Journal of Financial and Quantitative Analysis 36, 1-24.

Jensen, M.C., 1986. Agency costs of free cash flow, corporate finance, and take- overs. American Economic Review 76, 323-329.

Jensen, M.C., Meckling, W.H., 1976. Theory of the firm: managerial behavior, agency costs and ownership structure. Journal of Financial Economics 3, 305-360.

La Porta, R., Lopez-de-Silanes, F., Shleifer, A., Vishny, R.W., 1998. Law and finance. Journal of Political Economy 106, 1113-1155.

La Porta, R., Lopez-de-Silanes, F., Shleifer, A., Vishny, R.W. 2000. Agency problems around the world. Journal of Finance 55, 1-33.

Leland, H.E., Pyle, D.H., 1977. Informational asymmetries, financial structure, and financial intermediation. Journal of Finance 32, 371-387. 
Leland, H.E., Toft, K.B., 1996. Optimal capital structure, endogenous bankruptcy, and the term structure of credit spreads. Journal of Finance 51, 987-1019.

Myers, S.C., 1977. Determinants of corporate borrowing. Journal of Financial Economics 5, 147-175.

Myers, S.C., Majluf, N., 1984. Corporate financing and investment decisions when firms have information that investors do not have. Journal of Financial Economics 13, 3-46.

Miller, M.H., 1977. Debt and taxes. Journal of Finance 32, 261-275.

Modigliani, F., Miller, M.H., 1958. The cost of capital, corporation financing and the theory of investment. American Economic Review 48, 261-297.

Modigliani, F., Miller, M.H., 1963. Taxes and the cost of capital: a correction. American Economic Review 53, 433-443.

Moore, J.S., Reichert, A.K., 1983. An analysis of the financial management techniques currently employed by large U.S. corporations. Journal of Business Finance and Accounting 10, 623-645.

Opler, T.C., Pinkowitz, L., Stulz, R., Williamson, R., 1999. The determinants and implications of corporate cash holdings. Journal of Financial Economics 52, 3-46.

Peterson, B., Harrell Jr, F.E., 1990. Partial proportional odds models for ordinal response variables. Applied Statistics 39, 205-217.

Pochet, C. 2002. Institutional complementarities within corporate governance systems: a comparative study of bankruptcy rules. Journal of Management and Governance 6, 343-381.

Rajan, R.G., Zingales, L., 1995. What do we know about capital structure? Some evidence from international data. Journal of Finance 50, 1421-1460.

Rajan, R.G., Zingales, L., 2003. The great reversals: the politics of financial development in the twentieth century. Journal of Financial Economics 69, 5-50.

Ross, S.A., 1977. The determination of financial structure: the incentive signaling approach. Bell Journal of Economics 8, 1-32.

Stein, J.C., 1992. Convertible bonds as backdoor equity financing. Journal of Financial Economics 32, 3-21.

Stulz, R., 1988. Managerial control of voting rights: financing policies and the market for corporate control. Journal of Financial Economics 20, 25-54.

Titman, S., 1984. The effect of capital structure on a firm's liquidation decision. Journal of Financial Economics 13, 137-151.

Trahan, E.A., Gitman, L.J., 1995. Bridging the theory-practice gap in corporate finance: a survey of chief financial officers. Quarterly Review of Economics and Finance 35, 73-87.

Welch, I., 2004. Capital structure and stock returns. Journal of Political Economy 112, 106-131.

Williamson, O.E., 1988. Corporate finance and corporate governance. Journal of Finance 43, 567-591. 
Table 1: Sample statistics

\begin{tabular}{|c|c|c|c|c|c|c|c|}
\hline & & U.K. & Netherlands & Germany & France & Europe (BM) & U.S. $(\mathrm{GH})$ \\
\hline \multirow{6}{*}{ Sales } & $<€ 25$ million & $29.41 \%$ & $7.84 \%$ & $8.40 \%$ & $30.51 \%$ & $0.00 \%$ & $7.91 \%$ \\
\hline & $€ 25-€ 99$ million & $35.29 \%$ & $39.22 \%$ & $34.35 \%$ & $32.20 \%$ & $1.15 \%$ & $16.84 \%$ \\
\hline & $€ 100-€ 499$ million & $16.18 \%$ & $25.49 \%$ & $38.17 \%$ & $16.95 \%$ & $9.20 \%$ & $22.19 \%$ \\
\hline & $€ 500-€ 999$ million & $4.41 \%$ & $7.84 \%$ & $6.87 \%$ & $5.08 \%$ & $8.05 \%$ & $8.42 \%$ \\
\hline & $€ 1000-€ 4999$ million & $8.82 \%$ & $9.80 \%$ & $9.92 \%$ & $5.08 \%$ & $41.38 \%$ & $22.70 \%$ \\
\hline & $>€ 4999$ million & $5.88 \%$ & $9.80 \%$ & $2.29 \%$ & $10.17 \%$ & $40.23 \%$ & $18.37 \%$ \\
\hline \multirow[t]{8}{*}{ Industry } & Retail and wholesale & $19.05 \%$ & $12.00 \%$ & $6.45 \%$ & $24.14 \%$ & $6.90 \%$ & $9.95 \%$ \\
\hline & Mining, construction & $4.76 \%$ & $2.00 \%$ & $9.68 \%$ & $18.97 \%$ & $16.09 \%$ & $3.57 \%$ \\
\hline & Manufacturing & $41.27 \%$ & $38.00 \%$ & $50.00 \%$ & $31.01 \%$ & $13.79 \%$ & $37.50 \%$ \\
\hline & Transportation, energy & $6.35 \%$ & $16.00 \%$ & $15.32 \%$ & $5.17 \%$ & $8.05 \%$ & $11.22 \%$ \\
\hline & Communication, media & $4.76 \%$ & $18.00 \%$ & $4.84 \%$ & $5.17 \%$ & $8.05 \%$ & $5.10 \%$ \\
\hline & Bank, finance, insurance & $9.52 \%$ & $10.00 \%$ & $2.42 \%$ & $3.45 \%$ & $18.39 \%$ & $13.78 \%$ \\
\hline & Tech (software, biotech, etc.) & $14.29 \%$ & $4.00 \%$ & $11.29 \%$ & $12.07 \%$ & $18.39 \%$ & $8.42 \%$ \\
\hline & Other & n.a. & n.a. & n.a. & n.a. & $10.34 \%$ & n.a. \\
\hline Publicly listed firm & & $53.73 \%$ & $41.18 \%$ & $22.73 \%$ & $11.67 \%$ & $100.00 \%$ & $65.56 \%$ \\
\hline Regulated utility & & $9.84 \%$ & $6.52 \%$ & $16.81 \%$ & $28.57 \%$ & $6.90 \%$ & $16.84 \%$ \\
\hline Dividend paying & & $61.19 \%$ & $74.51 \%$ & $51.54 \%$ & $71.19 \%$ & $96.55 \%$ & $56.38 \%$ \\
\hline \multirow[t]{3}{*}{ Considered issuing.... } & Common stock & $41.18 \%$ & $28.85 \%$ & $9.09 \%$ & $8.20 \%$ & $77.01 \%$ & $39.29 \%$ \\
\hline & Convertible debt & $11.76 \%$ & $13.46 \%$ & $3.79 \%$ & $14.75 \%$ & $50.57 \%$ & $24.49 \%$ \\
\hline & Foreign debt & $17.65 \%$ & $28.85 \%$ & $28.03 \%$ & $13.11 \%$ & $57.47 \%$ & $36.22 \%$ \\
\hline \multirow[t]{7}{*}{ Longterm debt ratio } & $0 \%$ & $25.00 \%$ & $6.52 \%$ & $12.73 \%$ & $28.57 \%$ & $1.15 \%$ & $9.06 \%$ \\
\hline & $1-9 \%$ & $10.71 \%$ & $2.17 \%$ & $8.18 \%$ & $8.57 \%$ & $17.24 \%$ & $10.27 \%$ \\
\hline & $10-19 \%$ & $12.50 \%$ & $13.04 \%$ & $20.00 \%$ & $14.29 \%$ & $22.99 \%$ & $12.99 \%$ \\
\hline & $20-29 \%$ & $7.14 \%$ & $23.91 \%$ & $12.73 \%$ & $8.57 \%$ & $14.94 \%$ & $16.62 \%$ \\
\hline & $30-39 \%$ & $14.29 \%$ & $19.57 \%$ & $15.45 \%$ & $14.29 \%$ & $6.90 \%$ & $16.92 \%$ \\
\hline & $40-49 \%$ & $8.93 \%$ & $10.87 \%$ & $9.09 \%$ & $11.43 \%$ & $8.05 \%$ & $12.39 \%$ \\
\hline & $>49 \%$ & $21.43 \%$ & $23.91 \%$ & $21.82 \%$ & $14.29 \%$ & $28.74 \%$ & $21.75 \%$ \\
\hline Number of firms & & 68 & 52 & 132 & 61 & 87 & 392 \\
\hline
\end{tabular}


Figure 1: Target debt ratio

US

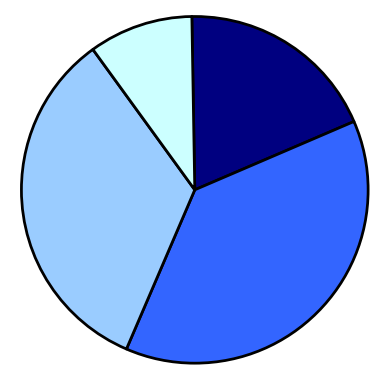

Netherlands

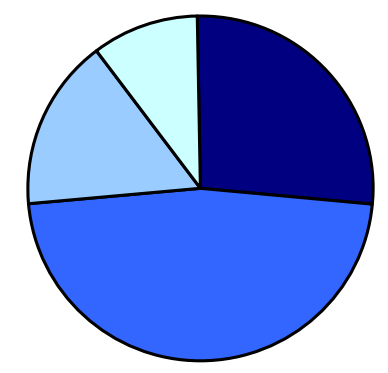

UK

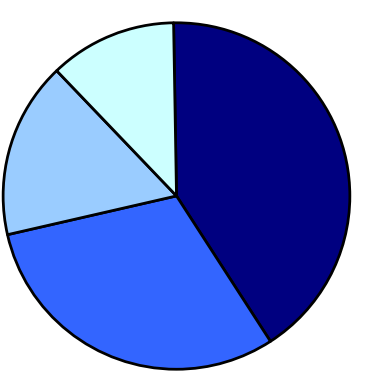

Germany

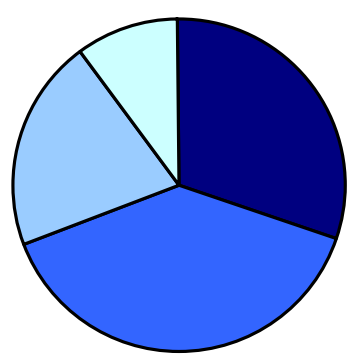

France

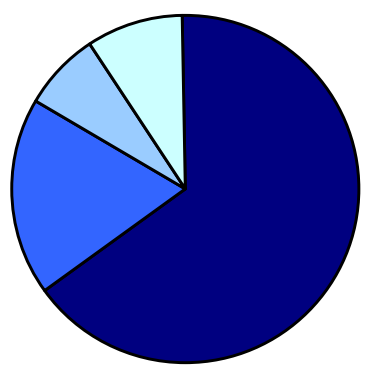

No target debt ratio

Flexible target debt ratio

Somewhat tight target debt ratio

Strict target debt ratio 
Table 2: Survey responses to the question "What factors affect how you choose the appropriate amount of debt for your firm?"

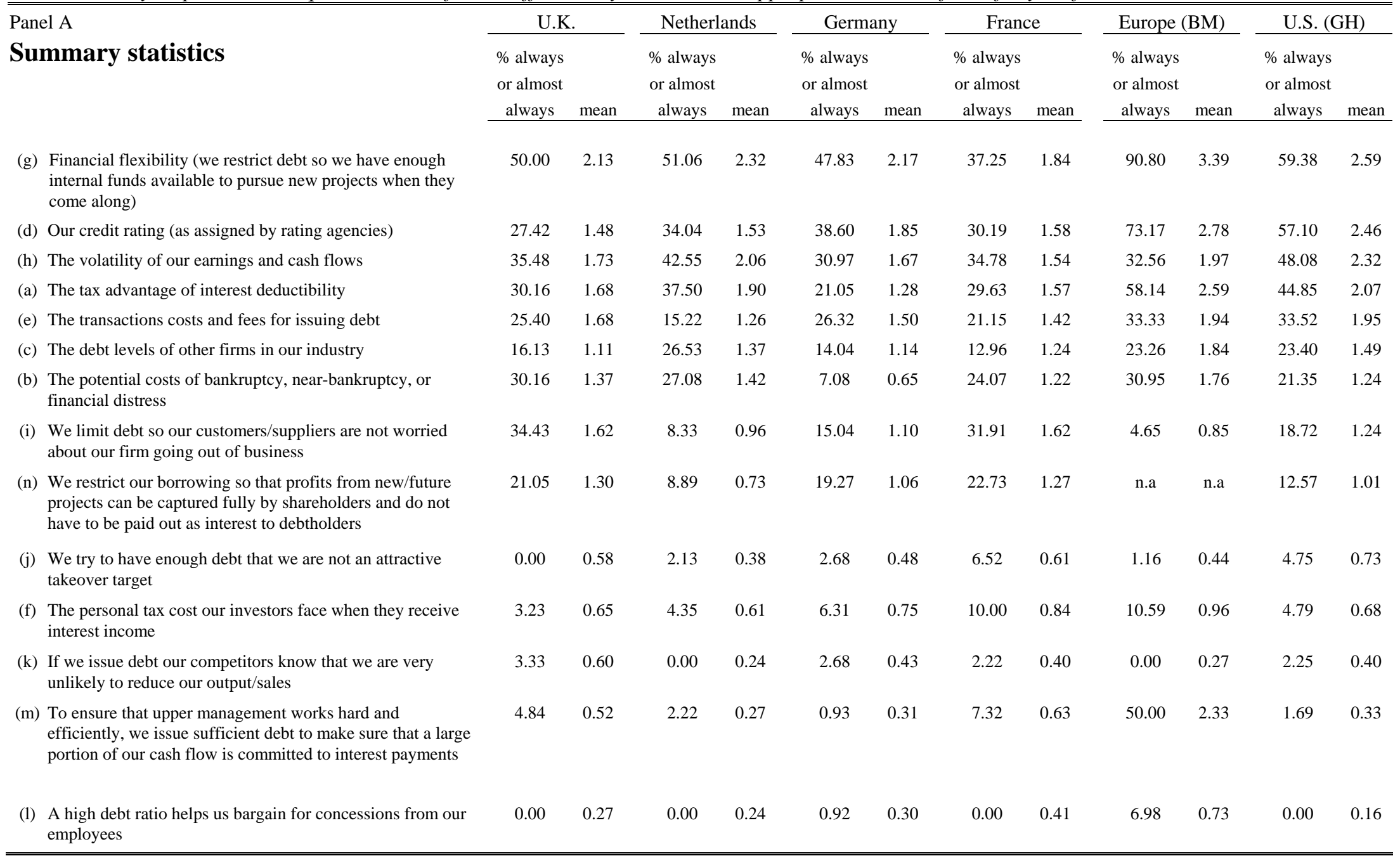


Table 2: Survey responses to the question "What factors affect how you choose the appropriate amount of debt for your firm?"

\section{Panel B \\ Leverage and target ratio breakdowns}

(g) Financial flexibility (we restrict debt so we have enough internal funds available to pursue new projects when they come along)

(d) Our credit rating (as assigned by rating agencies)

(h) The volatility of our earnings and cash flows

(a) The tax advantage of interest deductibility

(e) The transactions costs and fees for issuing debt

(c) The debt levels of other firms in our industry

(b) The potential costs of bankruptcy, near-bankruptcy, or financial distress

(i) We limit debt so our customers/suppliers are not worried about our firm going out of business

(n) We restrict our borrowing so that profits from new/future projects can be captured fully by shareholders and do not have to be paid out as interest to debtholders

(j) We try to have enough debt that we are not an attractive takeover target

(f) The personal tax cost our investors face when they receive interest income

(k) If we issue debt our competitors know that we are very unlikely to reduce our output/sales

(m) To ensure that upper management works hard and efficiently, we issue sufficient debt to make sure that a large portion of our cash flow is committed to interest payments

(l) A high debt ratio helps us bargain for concessions from our employees

\begin{tabular}{|c|c|c|c|c|c|c|c|c|c|c|c|c|c|c|c|}
\hline \multicolumn{4}{|c|}{ U.K. } & \multicolumn{4}{|c|}{ Netherlands } & \multicolumn{4}{|c|}{ Germany } & \multicolumn{4}{|c|}{ France } \\
\hline \multicolumn{2}{|c|}{ Leverage } & \multicolumn{2}{|c|}{ Target ratio } & \multicolumn{2}{|c|}{ Leverage } & \multicolumn{2}{|c|}{ Target ratio } & \multicolumn{2}{|c|}{ Leverage } & \multicolumn{2}{|c|}{ Target ratio } & \multicolumn{2}{|c|}{ Leverage } & \multicolumn{2}{|c|}{ Target ratio } \\
\hline Low & High & No & Yes & Low & High & No & Yes & Low & High & No & Yes & Low & High & No & Yes \\
\hline 1.88 & $2.83^{* * *}$ & 1.32 & $2.63^{* * *}$ & 2.41 & 2.17 & 2.29 & 2.33 & 2.21 & 2.09 & 2.17 & 2.16 & 1.81 & 2.00 & 1.61 & $2.40^{* * *}$ \\
\hline 1.36 & 1.63 & 1.00 & $1.77^{* * *}$ & 1.14 & $2.17^{*}$ & 1.29 & 1.64 & 1.71 & 2.07 & 1.08 & $2.21^{* * *}$ & 1.60 & 1.50 & 1.37 & 2.13 \\
\hline 1.29 & $2.26^{* *}$ & 1.12 & $2.17^{* * *}$ & 2.14 & 1.94 & 1.79 & 2.18 & 1.75 & 1.56 & 1.36 & $1.82^{*}$ & 1.50 & 1.83 & 1.15 & $2.54^{* * * *}$ \\
\hline 1.41 & $2.21^{*}$ & 0.76 & $2.33^{* * * *}$ & 1.93 & 1.84 & 1.36 & 2.12 & 1.23 & 1.36 & 1.00 & 1.41 & 1.57 & 1.60 & 1.50 & 1.75 \\
\hline 1.29 & $2.11^{* *}$ & 1.04 & $2.06^{* * * *}$ & 1.25 & 1.28 & 0.92 & 1.39 & 1.39 & 1.67 & 1.42 & 1.54 & 1.33 & 1.80 & 1.19 & $2.00^{*}$ \\
\hline 1.12 & 1.00 & 0.84 & $1.34^{*}$ & 0.87 & $2.16^{* * *}$ & 0.60 & $1.71^{* * *}$ & 1.07 & 1.24 & 0.83 & $1.28^{* *}$ & 1.25 & 1.20 & 1.21 & 1.31 \\
\hline 0.88 & $2.16^{* * * *}$ & 0.80 & $1.81^{* * * *}$ & 1.38 & 1.47 & 1.00 & 1.59 & 0.56 & 0.78 & 0.58 & 0.68 & 1.09 & 1.89 & 1.21 & 1.27 \\
\hline 1.27 & $2.06^{* *}$ & 1.08 & $2.03^{* * *}$ & 0.93 & 1.00 & 0.80 & 1.03 & 1.06 & 1.16 & 1.08 & 1.10 & 1.53 & 2.14 & 1.58 & 1.71 \\
\hline 1.27 & 1.29 & 1.08 & 1.44 & 0.86 & 0.50 & 0.92 & 0.66 & 1.24 & $0.77^{*}$ & 1.24 & 0.97 & 1.13 & $2.17^{*}$ & 1.19 & 1.50 \\
\hline 0.53 & 0.71 & 0.32 & $0.79^{* *}$ & 0.24 & 0.61 & 0.21 & 0.45 & 0.27 & $0.80^{* * * *}$ & 0.26 & $0.58^{* *}$ & 0.53 & 1.17 & 0.58 & 0.69 \\
\hline 0.50 & 0.68 & 0.52 & 0.69 & 0.68 & 0.50 & 0.29 & $0.75^{*}$ & 0.75 & 0.75 & 0.86 & 0.69 & 0.80 & 1.00 & 0.69 & 1.21 \\
\hline 0.55 & 0.74 & 0.60 & 0.64 & 0.21 & 0.29 & 0.15 & 0.27 & 0.33 & 0.58 & 0.42 & 0.43 & 0.31 & $1.00^{* *}$ & 0.36 & 0.50 \\
\hline 0.47 & 0.47 & 0.52 & 0.49 & 0.21 & 0.35 & 0.00 & $0.36^{* * *}$ & 0.28 & 0.36 & 0.25 & 0.35 & 0.66 & 0.50 & 0.60 & 0.73 \\
\hline 0.29 & 0.21 & 0.32 & 0.23 & 0.24 & 0.24 & 0.23 & 0.24 & 0.28 & 0.34 & 0.28 & 0.32 & 0.32 & 1.00 & 0.47 & 0.25 \\
\hline
\end{tabular}

Averages marked with,$*$, are significantly different ta a $10 \%, 5 \%$, and $1 \%$ confidence level from the average is the preceeding column, using a standard differences of means test. The letters in parenthesese in the left column refer to the questions in Graham and Harvey (2001). 
Table 3: Survey responses to the question "What other factors affect your firm's debt policy?"

\begin{tabular}{|c|c|c|c|c|c|c|c|c|c|c|c|c|c|}
\hline \multirow{2}{*}{\multicolumn{2}{|c|}{$\begin{array}{l}\text { Panel A } \\
\text { Summary statistics }\end{array}$}} & \multicolumn{2}{|c|}{ U.K. } & \multicolumn{2}{|c|}{ Netherlands } & \multicolumn{2}{|c|}{ Germany } & \multicolumn{2}{|c|}{ France } & \multicolumn{2}{|c|}{ Europe (BM) } & \multicolumn{2}{|c|}{ U.S. (GH) } \\
\hline & & $\begin{array}{c}\% \text { always } \\
\text { or almost } \\
\text { always }\end{array}$ & mean & $\begin{array}{c}\% \text { always } \\
\text { or almost } \\
\text { always }\end{array}$ & mean & $\begin{array}{c}\% \text { always } \\
\text { or almost } \\
\text { always }\end{array}$ & mean & $\begin{array}{c}\text { \% always } \\
\text { or almost } \\
\text { always }\end{array}$ & mean & $\begin{array}{c}\% \text { always } \\
\text { or almost } \\
\text { always }\end{array}$ & mean & $\begin{array}{c}\text { \% always } \\
\text { or almost } \\
\text { always }\end{array}$ & mean \\
\hline (c) & We issue debt when interest rates are particularly low & 29.31 & 1.53 & 14.89 & 1.19 & 32.76 & 1.87 & 24.49 & 1.33 & 44.83 & 2.10 & 46.35 & 2.22 \\
\hline (a) & $\begin{array}{l}\text { We issue debt when our recent profits (internal funds) are } \\
\text { not sufficient to fund our activities }\end{array}$ & 25.42 & 1.44 & 34.69 & 1.69 & 54.31 & 2.30 & 23.53 & 1.24 & 24.14 & 1.56 & 46.78 & 2.13 \\
\hline (d) & We use debt when our equity is undervalued by the market & 16.07 & 1.02 & 6.38 & 0.62 & 6.31 & 0.45 & 8.16 & 0.80 & 43.68 & 2.08 & 30.79 & 1.56 \\
\hline (g) & Changes in the price of our common stock & 8.93 & 0.82 & 4.44 & 0.60 & 2.80 & 0.46 & 4.65 & 0.65 & 15.12 & 1.34 & 16.38 & 1.08 \\
\hline (e) & $\begin{array}{l}\text { We delay issuing debt because of transactions costs and } \\
\text { fees }\end{array}$ & 3.64 & 0.75 & 2.13 & 0.40 & 5.26 & 0.75 & 8.33 & 0.71 & 5.81 & 0.92 & 10.17 & 1.06 \\
\hline (f) & $\begin{array}{l}\text { We delay retiring debt because of recapitalization costs and } \\
\text { fees }\end{array}$ & 0.00 & 0.53 & 2.13 & 0.55 & 7.02 & 0.89 & 4.35 & 0.59 & n.a. & n.a. & 12.43 & 1.04 \\
\hline (b) & $\begin{array}{l}\text { Using debt gives investors a better impression of our firm's } \\
\text { prospects than issuing stock }\end{array}$ & 8.77 & 0.91 & 2.08 & 0.65 & 4.31 & 0.75 & 11.76 & 1.06 & 20.00 & 1.55 & 9.83 & 0.96 \\
\hline (h) & $\begin{array}{l}\text { We issue debt when we have accumulated substantial } \\
\text { profits }\end{array}$ & 3.57 & 0.55 & 2.22 & 0.49 & 5.45 & 0.62 & 4.65 & 0.58 & 1.18 & 0.72 & 1.14 & 0.53 \\
\hline
\end{tabular}


Table 3: Survey responses to the question "What other factors affect your firm's debt policy?"

\begin{tabular}{|c|c|c|c|c|c|c|c|c|c|c|c|c|c|c|c|c|c|}
\hline \multirow{3}{*}{\multicolumn{2}{|c|}{$\begin{array}{l}\text { Panel B } \\
\text { Leverage and target ratio breakdowns }\end{array}$}} & \multicolumn{4}{|c|}{ U.K. } & \multicolumn{4}{|c|}{ Netherlands } & \multicolumn{4}{|c|}{ Germany } & \multicolumn{4}{|c|}{ France } \\
\hline & & \multicolumn{2}{|c|}{ Leverage } & \multicolumn{2}{|c|}{ Target ratio } & \multicolumn{2}{|c|}{ Leverage } & \multicolumn{2}{|c|}{ Target ratio } & \multicolumn{2}{|c|}{ Leverage } & \multicolumn{2}{|c|}{ Target ratio } & \multicolumn{2}{|c|}{ Leverage } & \multicolumn{2}{|c|}{ Target ratio } \\
\hline & & Low & High & No & Yes & Low & High & No & Yes & Low & High & No & Yes & Low & High & No & Yes \\
\hline (c) & We issue debt when interest rates are particularly low & 1.24 & $2.17^{* *}$ & 0.83 & $2.00^{* * *}$ & 1.45 & $0.78^{* *}$ & 1.29 & 1.15 & 1.80 & 1.98 & 1.68 & 1.96 & 1.25 & 1.67 & 1.29 & 1.43 \\
\hline (a) & $\begin{array}{l}\text { We issue debt when our recent profits (internal funds) are } \\
\text { not sufficient to fund our activities }\end{array}$ & 1.12 & $1.89^{*}$ & 1.04 & $1.76^{* *}$ & 1.80 & 1.53 & 1.40 & 1.82 & 2.11 & $2.60^{*}$ & 1.64 & $2.60^{* * *}$ & 1.13 & 1.64 & 0.97 & $1.81^{* * *}$ \\
\hline (d) & We use debt when our equity is undervalued by the market & 0.87 & 1.33 & 0.36 & $1.39^{* * * *}$ & 0.59 & 0.67 & 0.50 & 0.67 & 0.56 & 0.28 & 0.37 & 0.49 & 0.73 & 1.11 & 0.69 & 1.07 \\
\hline (g) & Changes in the price of our common stock & 0.81 & 0.83 & 0.30 & $1.16^{* * *}$ & 0.74 & 0.39 & 0.31 & 0.72 & 0.60 & $0.24^{* *}$ & 0.49 & 0.44 & 0.54 & $1.33^{*}$ & 0.61 & 0.75 \\
\hline (f) & $\begin{array}{l}\text { We delay retiring debt because of recapitalization costs and } \\
\text { fees }\end{array}$ & 0.50 & 0.59 & 0.39 & 0.58 & 0.69 & 0.33 & 0.21 & $0.70^{* *}$ & 0.90 & 0.87 & 1.00 & 0.83 & 0.46 & $1.11^{*}$ & 0.59 & 0.57 \\
\hline (b) & $\begin{array}{l}\text { Using debt gives investors a better impression of our firm's } \\
\text { prospects than issuing stock }\end{array}$ & 0.82 & 0.94 & 0.52 & $1.19^{* * *}$ & 0.69 & 0.58 & 0.57 & 0.68 & 0.61 & $0.98^{* * *}$ & 0.68 & 0.78 & 0.90 & $1.78^{*}$ & 0.89 & 1.47 \\
\hline (h) & $\begin{array}{l}\text { We issue debt when we have accumulated substantial } \\
\text { profits }\end{array}$ & 0.50 & 0.72 & 0.43 & 0.66 & 0.53 & 0.53 & 0.31 & 0.56 & 0.61 & 0.63 & 0.53 & 0.66 & 0.51 & 1.00 & 0.61 & 0.50 \\
\hline
\end{tabular}

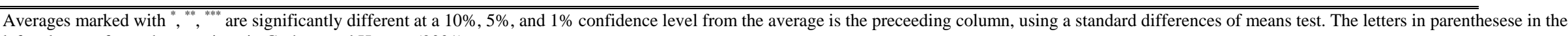
left column refer to the questions in Graham and Harvey (2001). 
Table 4: Ordered logit regression analysis on the question "What factors affect how you choose the appropriate amount of debt for your firm?"

\begin{tabular}{|c|c|c|c|c|c|c|c|c|c|c|c|c|c|c|c|c|}
\hline & & & & & & & \multicolumn{4}{|c|}{ Interaction: Public and ... } & \multicolumn{4}{|c|}{ Interaction: Private and ... } & \multirow[b]{2}{*}{$\mathrm{N}$} & \multirow[b]{2}{*}{$\mathrm{R}^{2}$} \\
\hline & & GR & FR & UK & US & Private & Lev & Tar & Size & Div & Lev & Tar & Size & Div & & \\
\hline (a) & $\begin{array}{l}\text { The tax advantage of interest } \\
\text { deductibility }\end{array}$ & $\begin{array}{l}-0.69^{* * *} \\
(-2.03)\end{array}$ & $\begin{array}{c}-0.16 \\
(-0.39)\end{array}$ & $\begin{array}{c}-0.25 \\
(-0.68)\end{array}$ & $\begin{array}{c}-0.01 \\
(-0.05)\end{array}$ & $\begin{array}{c}-0.35 \\
(-0.91)\end{array}$ & $\begin{array}{c}0.31 \\
(1.44)\end{array}$ & $\begin{array}{c}0.36 \\
(1.19)\end{array}$ & $\begin{array}{l}0.82^{* * * *} \\
(3.45)\end{array}$ & $\begin{array}{l}0.40^{*} \\
(1.65)\end{array}$ & $\begin{array}{c}0.11 \\
(0.47)\end{array}$ & $\begin{array}{l}0.78^{* * * *} \\
(3.13)\end{array}$ & $\begin{array}{l}0.75^{* *} \\
(2.04)\end{array}$ & $\begin{array}{c}0.25 \\
(1.09)\end{array}$ & 546 & 0.05 \\
\hline (d) & $\begin{array}{l}\text { Our credit rating (as assigned } \\
\text { by rating agencies) }\end{array}$ & $\begin{array}{l}0.96^{* * *} \\
(2.71)\end{array}$ & $\begin{array}{l}0.84^{* *} \\
(1.95)\end{array}$ & $\begin{array}{l}0.36 \\
(0.92)\end{array}$ & $\begin{array}{l}0.93^{* * *} \\
(2.86)\end{array}$ & $\begin{array}{c}-0.52 \\
(-1.31)\end{array}$ & $\begin{array}{l}0.43^{*} \\
(1.89)\end{array}$ & $\begin{array}{l}0.68^{*} \\
(2.22)\end{array}$ & $\begin{array}{l}1.67^{* * *} \\
(6.54)\end{array}$ & $\begin{array}{c}0.15 \\
(0.61)\end{array}$ & $\begin{array}{c}0.14 \\
(0.59)\end{array}$ & $\begin{array}{l}1.13^{* * *} \\
(4.34)\end{array}$ & $\begin{array}{l}0.92^{* *} \\
(2.40)\end{array}$ & $\begin{array}{c}0.16 \\
(0.67)\end{array}$ & 543 & 0.10 \\
\hline (e) & $\begin{array}{l}\text { The transactions costs and } \\
\text { fees for issuing debt }\end{array}$ & $\begin{array}{c}0.26 \\
(0.79)\end{array}$ & $\begin{array}{c}0.11 \\
(0.25)\end{array}$ & $\begin{array}{c}0.49 \\
(1.37)\end{array}$ & $\begin{array}{l}0.89^{* * *} \\
(2.94)\end{array}$ & $\begin{array}{c}-0.63 \\
(-1.61)\end{array}$ & $\begin{array}{c}-0.03 \\
(-0.12)\end{array}$ & $\begin{array}{l}0.68^{* *} \\
(2.12)\end{array}$ & $\begin{array}{c}-0.37 \\
(-1.58)\end{array}$ & $\begin{array}{c}-0.15 \\
(-0.60)\end{array}$ & $\begin{array}{l}0.44^{*} \\
(1.91)\end{array}$ & $\begin{array}{l}0.42 \\
(1.63)\end{array}$ & $\begin{array}{l}0.65^{*} \\
(1.82)\end{array}$ & $\begin{array}{c}0.18 \\
(0.78)\end{array}$ & 541 & 0.03 \\
\hline (f) & $\begin{array}{l}\text { The personal tax cost our } \\
\text { investors face when they } \\
\text { receive interest income }\end{array}$ & $\begin{array}{l}0.27 \\
(0.72)\end{array}$ & $\begin{array}{l}0.46 \\
(1.00)\end{array}$ & $\begin{array}{c}0.25 \\
(0.63)\end{array}$ & $\begin{array}{c}-0.02 \\
(-0.06)\end{array}$ & $\begin{array}{l}-0.96^{* *} \\
(-2.30)\end{array}$ & $\begin{array}{c}-0.23 \\
(-0.92)\end{array}$ & $\begin{array}{c}-0.43 \\
(-1.30)\end{array}$ & $\begin{array}{l}0.47^{*} \\
(1.73)\end{array}$ & $\begin{array}{l}0.05 \\
(0.19)\end{array}$ & $\begin{array}{l}0.18 \\
(0.71)\end{array}$ & $\begin{array}{l}0.64^{* *} \\
(2.18)\end{array}$ & $\begin{array}{c}-0.18 \\
(-0.45)\end{array}$ & $\begin{array}{c}0.04 \\
(0.17)\end{array}$ & 533 & 0.01 \\
\hline (g) & Financial flexibility & $\begin{array}{c}0.14 \\
(0.42)\end{array}$ & $\begin{array}{c}-0.62 \\
(-1.53)\end{array}$ & $\begin{array}{c}-0.20 \\
(-0.55)\end{array}$ & $\begin{array}{c}0.45 \\
(1.49)\end{array}$ & $\begin{array}{c}-0.62 \\
(-1.58)\end{array}$ & $\begin{array}{c}0.09 \\
(0.41)\end{array}$ & $\begin{array}{c}0.13 \\
(0.40)\end{array}$ & $\begin{array}{c}0.13 \\
(0.54)\end{array}$ & $\begin{array}{l}0.48^{*} \\
(1.85)\end{array}$ & $\begin{array}{c}-0.20 \\
(-0.91)\end{array}$ & $\begin{array}{l}0.47^{*} \\
(1.94)\end{array}$ & $\begin{array}{c}-0.21 \\
(-0.59)\end{array}$ & $\begin{array}{l}0.85^{* * *} \\
(3.71)\end{array}$ & 540 & 0.04 \\
\hline (h) & $\begin{array}{l}\text { The volatility of our earnings } \\
\text { and cash flows }\end{array}$ & $\begin{array}{c}-0.52 \\
(-1.59)\end{array}$ & $\begin{array}{c}-0.23 \\
(-0.53)\end{array}$ & $\begin{array}{c}-0.33 \\
(-0.90)\end{array}$ & $\begin{array}{c}0.18 \\
(0.59)\end{array}$ & $\begin{array}{c}-0.29 \\
(-0.76)\end{array}$ & $\begin{array}{c}0.14 \\
(0.62)\end{array}$ & $\begin{array}{l}0.66^{* *} \\
(2.20)\end{array}$ & $\begin{array}{c}-0.13 \\
(-0.56)\end{array}$ & $\begin{array}{c}-0.09 \\
(-0.35)\end{array}$ & $\begin{array}{c}-0.02 \\
(-0.11)\end{array}$ & $\begin{array}{l}0.79^{* * *} \\
(3.05)\end{array}$ & $\begin{array}{c}0.23 \\
(0.62)\end{array}$ & $\begin{array}{c}0.12 \\
(0.53)\end{array}$ & 539 & 0.02 \\
\hline (j) & $\begin{array}{l}\text { We try to have enough debt } \\
\text { that we are not an attractive } \\
\text { takeover target }\end{array}$ & $\begin{array}{c}0.60 \\
(1.49)\end{array}$ & $\begin{array}{l}1.25^{* *} \\
(2.49)\end{array}$ & $\begin{array}{l}0.78^{*} \\
(1.75)\end{array}$ & $\begin{array}{l}0.63^{*} \\
(1.74)\end{array}$ & $\begin{array}{l}-1.16^{* *} \\
(-2.42)\end{array}$ & $\begin{array}{c}0.12 \\
(0.49)\end{array}$ & $\begin{array}{l}0.88^{* *} \\
(2.46)\end{array}$ & $\begin{array}{l}0.28 \\
(1.08)\end{array}$ & $\begin{array}{c}-0.03 \\
(-0.13)\end{array}$ & $\begin{array}{l}1.02^{* * *} \\
(3.57)\end{array}$ & $\begin{array}{l}0.64^{*} \\
(1.94)\end{array}$ & $\begin{array}{c}-0.26 \\
(-0.54)\end{array}$ & $\begin{array}{c}-0.01 \\
(-0.04)\end{array}$ & 529 & 0.06 \\
\hline
\end{tabular}

In these pooled ordered logit regressions we regress the response on subquestions from Table 2 on country dummies, a dummy for private status (Private) and on a set of interaction terms. Germany is denoted as GR, France is FR. The Dutch observations serve as omitted variable. The coefficients under the heading "Interaction: public and..." are the interaction terms of a dummy variable with value of one (and zero otherwise) for public firms with four firm characteristics: Div is a dummy with a value equal to one if firms pay out dividend; Tar is a dummy with value equal to one if firms have a target debt ratio; and Lev and Size are dummy

variables with value of one if firms are in the cluster of most levered firms and largest firms, respectively. Similarly, the coefficients under the heading "Interaction: private and..." are the interaction terms of a dummy

variable with value of one for private firms with the four firm characteristics. The z-statistics are in parentheses below each coefficient. Coefficients marked with ", ${ }^{* * *}$, ${ }^{* * * *}$ are statistically significant at a a $10 \%$, $5 \%$, and

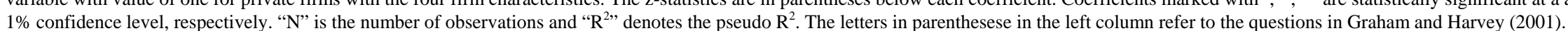


Table 5: Ordered logit regression analysis on the question "What other factors affect your firm's debt policy?"

\begin{tabular}{|c|c|c|c|c|c|c|c|c|c|c|c|c|c|c|c|}
\hline & & & & & & \multicolumn{4}{|c|}{ Interaction Public with ... } & \multicolumn{4}{|c|}{ Interaction Private with ... } & \multirow[b]{2}{*}{$\mathrm{N}$} & \multirow[b]{2}{*}{$\mathrm{R}^{2}$} \\
\hline & GR & FR & UK & US & Private & Lev & Tar & Size & Div & Lev & Tar & Size & Div & & \\
\hline $\begin{array}{l}\text { We issue debt when our recent } \\
\text { profits are not sufficient to fund } \\
\text { our activities }\end{array}$ & $\begin{array}{l}0.67^{* *} \\
(2.11)\end{array}$ & $\begin{array}{c}-0.65 \\
(-1.61)\end{array}$ & $\begin{array}{c}-0.42 \\
(-1.19)\end{array}$ & $\begin{array}{c}0.39 \\
(1.35)\end{array}$ & $\begin{array}{l}-0.25 \\
(-0.62)\end{array}$ & $\begin{array}{c}0.13 \\
(0.56)\end{array}$ & $\begin{array}{l}0.36 \\
(1.08)\end{array}$ & $\begin{array}{l}-0.47^{*} \\
(-1.94)\end{array}$ & $\begin{array}{c}0.10 \\
(0.38)\end{array}$ & $\begin{array}{c}0.18 \\
(0.79)\end{array}$ & $\begin{array}{l}0.78^{*+*+*} \\
(3.19)\end{array}$ & $\begin{array}{c}0.02 \\
(0.06)\end{array}$ & $\begin{array}{c}-0.03 \\
(-0.14)\end{array}$ & 539 & 0.03 \\
\hline $\begin{array}{l}\text { Using debt gives investors a } \\
\text { better impression of our firm's } \\
\text { prospects }\end{array}$ & $\begin{array}{c}0.39 \\
(1.11)\end{array}$ & $\begin{array}{l}0.81^{*} \\
(1.87)\end{array}$ & $\begin{array}{c}0.53 \\
(1.35)\end{array}$ & $\begin{array}{c}0.35 \\
(1.09)\end{array}$ & $\begin{array}{c}-0.72^{*} \\
(-1.75)\end{array}$ & $\begin{array}{c}0.20 \\
(0.87)\end{array}$ & $\begin{array}{l}0.59^{*} \\
(1.74)\end{array}$ & $\begin{array}{c}0.11 \\
(0.43)\end{array}$ & $\begin{array}{c}-0.18 \\
(-0.70)\end{array}$ & $\begin{array}{l}0.47^{*} \\
(1.96)\end{array}$ & $\begin{array}{c}0.25 \\
(0.93)\end{array}$ & $\begin{array}{c}-0.54 \\
(-1.27)\end{array}$ & $\begin{array}{c}0.25 \\
(1.04)\end{array}$ & 535 & 0.03 \\
\hline $\begin{array}{l}\text { We issue debt when interest } \\
\text { rates are particularly low }\end{array}$ & $\begin{array}{l}1.06^{* * *} \\
(3.27)\end{array}$ & $\begin{array}{c}0.37 \\
(0.87)\end{array}$ & $\begin{array}{c}0.47 \\
(1.29)\end{array}$ & $\begin{array}{l}1.30^{*+*+4} \\
(4.39)\end{array}$ & $\begin{array}{c}-0.23 \\
(-0.59)\end{array}$ & $\begin{array}{c}0.02 \\
(0.08)\end{array}$ & $\begin{array}{l}0.76^{* *} \\
(2.50)\end{array}$ & $\begin{array}{c}0.04 \\
(0.16)\end{array}$ & $\begin{array}{c}0.07 \\
(0.28)\end{array}$ & $\begin{array}{c}-0.13 \\
(-0.57)\end{array}$ & $\begin{array}{c}0.34 \\
(1.34)\end{array}$ & $\begin{array}{c}0.52 \\
(1.39)\end{array}$ & $\begin{array}{c}0.38 \\
(1.62)\end{array}$ & 533 & 0.04 \\
\hline $\begin{array}{l}\text { We use debt when our equity is } \\
\text { undervalued by the market }\end{array}$ & $\begin{array}{c}-0.06 \\
(-0.15)\end{array}$ & $\begin{array}{l}1.27^{*+* *} \\
(2.58)\end{array}$ & $\begin{array}{c}0.67 \\
(1.58)\end{array}$ & $\begin{array}{l}1.01^{* *+*} \\
(2.87)\end{array}$ & $\begin{array}{l}-2.43^{* * *} \\
(-5.17)\end{array}$ & $\begin{array}{c}-0.05 \\
(-0.21)\end{array}$ & $\begin{array}{l}0.97^{* * *} \\
(2.88)\end{array}$ & $\begin{array}{c}-0.11 \\
(-0.45)\end{array}$ & $\begin{array}{l}-0.55^{* *} \\
(-2.14)\end{array}$ & $\begin{array}{c}0.25 \\
(0.80)\end{array}$ & $\begin{array}{l}0.27 \\
(0.78)\end{array}$ & $\begin{array}{c}0.32 \\
(0.69)\end{array}$ & $\begin{array}{c}0.07 \\
(0.23)\end{array}$ & 526 & 0.16 \\
\hline $\begin{array}{l}\text { We delay issuing debt because } \\
\text { of transactions costs and fees }\end{array}$ & $\begin{array}{l}0.80^{* *} \\
(2.15)\end{array}$ & $\begin{array}{l}0.87^{*} \\
(1.88)\end{array}$ & $\begin{array}{l}0.87^{* *} \\
(2.11)\end{array}$ & $\begin{array}{l}1.37^{4+*+*} \\
(2.94)\end{array}$ & $\begin{array}{l}-0.98^{* *} \\
(-2.29)\end{array}$ & $\begin{array}{c}-0.26 \\
(-1.09)\end{array}$ & $\begin{array}{l}0.73^{* *} \\
(2.10)\end{array}$ & $\begin{array}{l}-0.70^{* * *} \\
(-2.75)\end{array}$ & $\begin{array}{c}-0.38 \\
(-1.45)\end{array}$ & $\begin{array}{c}-0.08 \\
(-0.35)\end{array}$ & $\begin{array}{l}0.69^{n+2+*} \\
(2.64)\end{array}$ & $\begin{array}{c}0.39 \\
(1.00)\end{array}$ & $\begin{array}{c}0.26 \\
(1.03)\end{array}$ & 527 & 0.05 \\
\hline $\begin{array}{l}\text { Changes in the price of our } \\
\text { common stock }\end{array}$ & $\begin{array}{c}0.21 \\
(0.49)\end{array}$ & $\begin{array}{c}0.84 \\
(1.53)\end{array}$ & $\begin{array}{c}0.69 \\
(1.58)\end{array}$ & $\begin{array}{c}0.53 \\
(1.47)\end{array}$ & $\begin{array}{c}-1.94^{* * *} \\
(-4.15)\end{array}$ & $\begin{array}{c}0.10 \\
(0.45)\end{array}$ & $\begin{array}{l}0.90^{* * * *} \\
(2.69)\end{array}$ & $\begin{array}{c}0.17 \\
(0.68)\end{array}$ & $\begin{array}{l}-0.74^{* * * *} \\
(-2.80)\end{array}$ & $\begin{array}{c}0.05 \\
(0.18)\end{array}$ & $\begin{array}{c}0.06 \\
(0.18)\end{array}$ & $\begin{array}{c}-0.35 \\
(-0.61)\end{array}$ & $\begin{array}{c}0.26 \\
(0.79)\end{array}$ & 510 & 0.13 \\
\hline
\end{tabular}

In these pooled ordered logit regressions we regress the response on subquestions from Table 3 on country dummies, a dummy for private status (Private) and on a set of interaction terms. Germany is denoted as GR, France is FR. The Dutch observations serve as omitted variable. The coefficients under the heading "Interaction: public and...” are the interaction terms of a dummy variable with value of one (and zero otherwise) for public firms with four firm characteristics: Div is a dummy with a value equal to one if firms pay out dividend; Tar is a dummy with value equal to one if firms have a target debt ratio; and Lev and Size are dummy variables with value of one if firms are in the cluster of most levered firms and largest firms, respectively. Similarly, the coefficients under the heading "Interaction: private and...” are the interaction terms of a dummy variable with value of one for private firms with the four firm characteristics. The z-statistics are in parentheses below each coefficient. Coefficients marked with ${ }^{*}$, ${ }^{* *}$, **** are statistically significant at a a $10 \%, 5 \%$, and

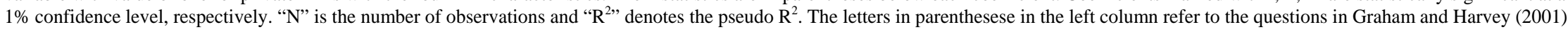


Table 6: Survey responses to the question "Has your firm seriously considered issuing debt in foreign countries? If "yes", what factors affect your firm's decisions about issuing foreign debt?"

\begin{tabular}{|c|c|c|c|c|c|c|c|c|c|c|c|c|c|}
\hline \multirow{3}{*}{\multicolumn{2}{|c|}{ Summary statistics }} & \multicolumn{2}{|c|}{ U.K. } & \multicolumn{2}{|c|}{ Netherlands } & \multicolumn{2}{|c|}{ Germany } & \multicolumn{2}{|c|}{ France } & \multicolumn{2}{|c|}{ Europe (BM) } & \multicolumn{2}{|c|}{ U.S. (GH) } \\
\hline & & $\begin{array}{l}\% \text { always } \\
\text { or almost }\end{array}$ & & $\begin{array}{l}\% \text { always } \\
\text { or almost }\end{array}$ & & $\begin{array}{l}\% \text { always } \\
\text { or almost }\end{array}$ & & $\begin{array}{l}\% \text { always } \\
\text { or almos }\end{array}$ & & $\begin{array}{l}\% \text { always } \\
\text { or almost }\end{array}$ & & $\begin{array}{l}\% \text { always } \\
\text { or almost }\end{array}$ & \\
\hline & & always & mean & always & mean & always & mean & always & mean & always & mean & always & mean \\
\hline (c) & $\begin{array}{l}\text { Providing a "natural hedge" (e.g.: if the foreign currency } \\
\text { devalues, we are not obligated to pay interest in own } \\
\text { currency) }\end{array}$ & 90.91 & 3.09 & 38.46 & 1.54 & 41.18 & 2.00 & 37.50 & 1.75 & n.a. & n.a. & 85.84 & 3.15 \\
\hline (b) & Keeping the "source of funds" close to the "use of funds" & 72.73 & 2.55 & 50.00 & 1.93 & 45.45 & 1.88 & 50.00 & 2.00 & n.a. & n.a. & 63.39 & 2.67 \\
\hline (a) & $\begin{array}{l}\text { Favorable tax treatment relative to the home country name } \\
\text { (e.g.: different corporate tax rates) }\end{array}$ & 36.36 & 2.27 & 42.86 & 2.00 & 39.39 & 1.79 & 25.00 & 1.00 & n.a. & n.a. & 52.25 & 2.26 \\
\hline (e) & $\begin{array}{l}\text { Foreign interest rates may be lower than domestic interest } \\
\text { rates }\end{array}$ & 9.09 & 1.36 & 58.33 & 2.42 & 60.61 & 2.64 & 25.00 & 1.38 & n.a. & n.a. & 44.25 & 2.19 \\
\hline (d) & Foreign regulations require us to issue debt abroad & 0.00 & 0.64 & 23.08 & 1.00 & 6.45 & 0.65 & 0.00 & 0.63 & n.a. & n.a. & 5.50 & 0.63 \\
\hline
\end{tabular}

"n.a." is not available. The question in this table is not included in Bancel and Mittoo (2004). The letters in parenthesese in the left column refer to the questions in Graham and Harvey (2001). 
Table 7: Survey responses to the question "Has your firm seriously considered issuing common stock? If "yes", what factors affect your firm's decisions about issuing common stock?"

\begin{tabular}{|c|c|c|c|c|c|c|c|c|c|c|c|c|c|}
\hline \multirow{3}{*}{\multicolumn{2}{|c|}{ Summary statistics }} & \multicolumn{2}{|c|}{ U.K. } & \multicolumn{2}{|c|}{ Netherlands } & \multicolumn{2}{|c|}{ Germany } & \multicolumn{2}{|c|}{ France } & \multicolumn{2}{|c|}{ Europe (BM) } & \multicolumn{2}{|c|}{ U.S. (GH) } \\
\hline & & $\begin{array}{l}\% \text { always } \\
\text { or almost }\end{array}$ & & $\begin{array}{l}\% \text { always } \\
\text { or almost }\end{array}$ & & $\begin{array}{l}\% \text { always } \\
\text { or almost }\end{array}$ & & $\begin{array}{l}\% \text { always } \\
\text { or almost }\end{array}$ & & $\begin{array}{l}\% \text { always } \\
\text { or almost }\end{array}$ & & $\begin{array}{l}\% \text { always } \\
\text { or almost }\end{array}$ & \\
\hline & & always & mean & always & mean & always & mean & always & mean & always & mean & always & mean \\
\hline (m) & Earnings per share dilution & 39.13 & 2.04 & 53.85 & 2.23 & 0.00 & 0.42 & 0.00 & 0.00 & 66.04 & 2.72 & 68.55 & 2.84 \\
\hline (k) & $\begin{array}{l}\text { The amount by which our stock is undervalued or overvalued } \\
\text { by the market }\end{array}$ & 52.17 & 2.17 & 38.46 & 1.69 & 41.67 & 1.92 & 33.33 & 2.00 & 53.70 & 2.44 & 66.94 & 2.69 \\
\hline (a) & $\begin{array}{l}\text { If our stock price has recently risen, the price at which we can } \\
\text { issue is "high" }\end{array}$ & 52.00 & 2.24 & 46.15 & 1.77 & 33.33 & 1.50 & 40.00 & 1.40 & 59.26 & 2.61 & 62.60 & 2.53 \\
\hline (c) & Providing shares to employee bonus/stock option plans & 56.00 & 2.44 & 46.15 & 1.92 & 41.67 & 2.17 & 0.00 & 1.40 & 44.44 & 2.07 & 53.28 & 2.34 \\
\hline (e) & Maintaining target debt-to-equity ratio & 40.00 & 1.72 & 61.54 & 2.85 & 8.33 & 1.08 & 60.00 & 2.80 & 59.26 & 2.67 & 51.59 & 2.26 \\
\hline (j) & Diluting the holdings of certain shareholders & 30.43 & 1.70 & 38.46 & 1.85 & 8.33 & 0.83 & 33.33 & 1.67 & 29.63 & 1.67 & 50.41 & 2.14 \\
\hline (b) & Stock is our "least risky" source of funds & 24.00 & 1.76 & 30.77 & 1.62 & 25.00 & 1.42 & 40.00 & 2.00 & 25.93 & 1.50 & 30.58 & 1.76 \\
\hline (g) & $\begin{array}{l}\text { Whether our recent profits have been sufficient to fund our } \\
\text { activities }\end{array}$ & 43.48 & 1.91 & 35.71 & 1.86 & 50.00 & 1.83 & 40.00 & 2.00 & 32.08 & 1.94 & 30.40 & 1.76 \\
\hline (f) & $\begin{array}{l}\text { Using a similar amount of equity as is used by other firms in } \\
\text { our industry }\end{array}$ & 13.04 & 1.00 & 15.38 & 1.08 & 8.33 & 0.92 & 20.00 & 1.80 & 27.78 & 1.85 & 22.95 & 1.45 \\
\hline (h) & $\begin{array}{l}\text { Issuing stock gives investors a better impression of our firm's } \\
\text { prospects than using debt }\end{array}$ & 18.18 & 1.41 & 15.38 & 1.31 & 16.67 & 1.42 & 0.00 & 0.33 & 9.06 & 1.15 & 21.49 & 1.31 \\
\hline (l) & $\begin{array}{l}\text { Inability to obtain funds using debt, convertibles, or other } \\
\text { sources }\end{array}$ & 18.18 & 1.00 & 46.67 & 1.67 & 0.00 & 0.17 & 0.00 & 0.00 & 5.56 & 0.93 & 15.57 & 1.15 \\
\hline (d) & Common stock is our cheapest source of funds & 12.00 & 1.28 & 0.00 & 0.92 & 16.67 & 1.33 & 50.00 & 2.00 & 7.41 & 0.67 & 14.05 & 1.10 \\
\hline (i) & $\begin{array}{l}\text { The capital gains tax rates faced by our investors (relative to } \\
\text { tax rates on dividends) }\end{array}$ & 4.76 & 0.71 & 14.29 & 1.00 & 8.33 & 0.83 & 33.33 & 1.33 & 7.41 & 0.98 & 5.00 & 0.82 \\
\hline
\end{tabular}

The letters in parenthesese in the left column refer to the questions in Graham and Harvey (2001). 
Table 8: Survey responses to the question "Has your firm seriously considered issuing convertible debt? If "yes", what factors affect your firm's decisions about issuing convertible debt?"

\begin{tabular}{|c|c|c|c|c|c|c|c|c|c|c|c|c|c|}
\hline \multirow{3}{*}{\multicolumn{2}{|c|}{ Summary statistics }} & \multicolumn{2}{|c|}{ U.K. } & \multicolumn{2}{|c|}{ Netherlands } & \multicolumn{2}{|c|}{ Germany } & \multicolumn{2}{|c|}{ France } & \multicolumn{2}{|c|}{ Europe (BM) } & \multicolumn{2}{|c|}{ U.S. (GH) } \\
\hline & & $\begin{array}{l}\% \text { always } \\
\text { or almost }\end{array}$ & & $\begin{array}{l}\% \text { always } \\
\text { or almost }\end{array}$ & & $\begin{array}{l}\% \text { always } \\
\text { or almost }\end{array}$ & & $\begin{array}{l}\% \text { always } \\
\text { or almost }\end{array}$ & & $\begin{array}{l}\text { \% always } \\
\text { or almost }\end{array}$ & & $\begin{array}{l}\% \text { always } \\
\text { or almost }\end{array}$ & \\
\hline & & always & mean & always & mean & always & mean & always & mean & always & mean & always & mean \\
\hline (a) & $\begin{array}{l}\text { Convertibles are an inexpensive way to issue "delayed" } \\
\text { common stock }\end{array}$ & 50.00 & 2.50 & 66.67 & 2.83 & 40.00 & 2.60 & 25.00 & 1.50 & 57.14 & 2.45 & 58.11 & 2.49 \\
\hline (f) & Our stock is currently undervalued & 33.33 & 2.17 & 33.33 & 2.17 & 80.00 & 3.20 & 0.00 & 0.25 & 51.16 & 2.40 & 50.68 & 2.34 \\
\hline (g) & $\begin{array}{l}\text { Ability to "call" or force conversion of convertible debt } \\
\text { if/when we need to }\end{array}$ & 80.00 & 3.00 & 16.67 & 1.17 & 20.00 & 1.20 & 12.50 & 1.63 & 54.76 & 2.43 & 47.95 & 2.29 \\
\hline (e) & Avoiding short-term equity dilution & 33.33 & 2.17 & 83.33 & 3.17 & 0.00 & 1.00 & 37.50 & 2.13 & 51.16 & 2.16 & 45.83 & 2.18 \\
\hline (h) & $\begin{array}{l}\text { To attract investors unsure about the riskiness of our } \\
\text { company }\end{array}$ & 0.00 & 1.00 & 50.00 & 2.33 & 60.00 & 2.40 & 16.67 & 0.67 & 26.83 & 1.68 & 43.84 & 2.07 \\
\hline (c) & Convertibles are less expensive than straight debt & 50.00 & 2.33 & 50.00 & 1.83 & 75.00 & 3.00 & 12.50 & 1.38 & 35.71 & 1.86 & 41.67 & 1.85 \\
\hline (d) & Other firms in our industry successfully use convertibles & 0.00 & 0.80 & 16.67 & 1.67 & 0.00 & 0.60 & 12.50 & 0.75 & 18.60 & 1.09 & 12.50 & 1.10 \\
\hline (b) & $\begin{array}{l}\text { Protecting bondholders against unfavorable actions by } \\
\text { managers or stockholders }\end{array}$ & 20.00 & 1.00 & 0.00 & 0.67 & 0.00 & 0.80 & 0.00 & 0.38 & 4.65 & 0.88 & 1.41 & 0.62 \\
\hline
\end{tabular}

The letters in parenthesese in the left column refer to the questions in Graham and Harvey (2001). 
Table 9: Survey responses to the question "What factors affect your firm's choice between short-and long-term debt?"

\begin{tabular}{|c|c|c|c|c|c|c|c|c|c|c|c|c|c|}
\hline \multirow{2}{*}{\multicolumn{2}{|c|}{$\begin{array}{l}\text { Panel A } \\
\text { Summary statistics }\end{array}$}} & \multicolumn{2}{|c|}{ U.K. } & \multicolumn{2}{|c|}{ Netherlands } & \multicolumn{2}{|c|}{ Germany } & \multicolumn{2}{|c|}{ France } & \multicolumn{2}{|c|}{ Europe (BM) } & \multicolumn{2}{|c|}{ U.S. (GH) } \\
\hline & & $\begin{array}{l}\% \text { always } \\
\text { or almost }\end{array}$ & ברכ" & $\begin{array}{l}\% \text { always } \\
\text { or almost }\end{array}$ & 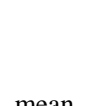 & $\begin{array}{l}\% \text { always } \\
\text { or almost }\end{array}$ & meכn & $\begin{array}{l}\% \text { always } \\
\text { or almost }\end{array}$ & mera & $\begin{array}{l}\% \text { always } \\
\text { or almost }\end{array}$ & mean & $\begin{array}{l}\% \text { always } \\
\text { or almost }\end{array}$ & \\
\hline (b) & Matching the maturity of our debt with the life of our assets & 58.73 & 2.16 & 57.45 & 2.55 & 60.34 & 2.55 & 31.91 & 1.68 & 77.01 & 3.10 & 63.25 & 2.60 \\
\hline (g) & $\begin{array}{l}\text { We issue long-term debt to minimize the risk of having to } \\
\text { refinance in "bad times" }\end{array}$ & 28.81 & 1.39 & 47.62 & $1.90^{* * *}$ & 51.75 & 2.24 & 31.91 & 1.68 & 69.77 & 2.83 & 48.83 & 2.15 \\
\hline (a) & $\begin{array}{l}\text { We issue short term when short term interest rates are low } \\
\text { compared to long term rates }\end{array}$ & 16.39 & 1.11 & 25.00 & 1.48 & 37.39 & 1.93 & 30.19 & 1.58 & n.a. & n.a. & 35.94 & 1.89 \\
\hline (c) & $\begin{array}{l}\text { We issue short-term when we are waiting for long-term } \\
\text { market interest rates to decline }\end{array}$ & 11.48 & 0.89 & 13.95 & 1.05 & 37.39 & 1.90 & 16.98 & 1.15 & 31.03 & 1.85 & 28.70 & 1.78 \\
\hline (d) & $\begin{array}{l}\text { We borrow short-term so that returns from new projects } \\
\text { can be captured more fully by shareholders. rather than } \\
\text { committing to pay long-term profits as interest to } \\
\text { debtholders }\end{array}$ & 12.90 & 0.82 & 9.09 & $0.80^{* * *}$ & 4.42 & 0.54 & 13.21 & 0.83 & 5.75 & 1.02 & 9.48 & 0.94 \\
\hline (e) & $\begin{array}{l}\text { We expect our credit rating to improve. so we borrow } \\
\text { short-term until it does }\end{array}$ & 5.00 & 0.57 & 4.65 & 0.47 & 7.89 & 0.58 & 11.76 & 0.75 & 7.14 & 0.90 & 8.99 & 0.85 \\
\hline (f) & $\begin{array}{l}\text { Borrowing short-term reduces the chance that our firm will } \\
\text { want to take on risky projects }\end{array}$ & 1.72 & 0.45 & 2.33 & 0.40 & 6.31 & 0.59 & 15.22 & 0.83 & 1.16 & 0.53 & 4.02 & 0.53 \\
\hline
\end{tabular}


Table 9: Survey responses to the question "What factors affect your firm's choice between short-and long-term debt?"

\begin{tabular}{|c|c|c|c|c|c|c|c|c|c|c|c|c|c|c|c|c|c|}
\hline \multirow{2}{*}{\multicolumn{2}{|c|}{$\begin{array}{l}\text { Panel B } \\
\text { Leverage and target ratio breakdowns }\end{array}$}} & \multicolumn{4}{|c|}{ U.K. } & \multicolumn{4}{|c|}{ Netherlands } & \multicolumn{4}{|c|}{ Germany } & \multicolumn{4}{|c|}{ France } \\
\hline & & \multicolumn{2}{|c|}{ Leverage } & \multicolumn{2}{|c|}{ Target ratio } & \multicolumn{2}{|c|}{ Leverage } & \multicolumn{2}{|c|}{ Target ratio } & \multicolumn{2}{|c|}{ Leverage } & \multicolumn{2}{|c|}{ Target ratio } & \multicolumn{2}{|c|}{ Leverage } & \multicolumn{2}{|c|}{ Target ratio } \\
\hline & & Low & High & No & Yes & Low & High & No & Yes & Low & High & No & Yes & Low & High & No & Yes \\
\hline (g) & $\begin{array}{l}\text { We issue long-term debt to minimize the risk of having to } \\
\text { refinance in "bad times" }\end{array}$ & 0.91 & $2.17^{* * *}$ & 0.46 & $2.03^{* * *}$ & 1.87 & 1.95 & 1.57 & 2.07 & 1.93 & $2.71^{* * * *}$ & 2.03 & 2.33 & 1.59 & 2.13 & 1.31 & $2.47^{* * *}$ \\
\hline (a) & $\begin{array}{l}\text { We issue short term when short term interest rates are low } \\
\text { compared to long term rates }\end{array}$ & 0.94 & 1.44 & 0.50 & $1.50^{* * *}$ & 1.56 & 1.37 & 1.53 & 1.45 & 1.90 & 1.98 & 1.79 & 2.00 & 1.47 & 2.10 & 1.61 & 1.53 \\
\hline (c) & $\begin{array}{l}\text { We issue short-term when we are waiting for long-term } \\
\text { market interest rates to decline }\end{array}$ & 0.55 & $1.44^{* * *}$ & 0.38 & $1.22^{* * *}$ & 1.17 & 0.89 & 0.71 & 1.21 & 1.80 & 2.04 & 1.54 & $2.06^{*}$ & 1.07 & 1.56 & 1.06 & 1.35 \\
\hline (d) & $\begin{array}{l}\text { We borrow short-term so that returns from new projects } \\
\text { can be captured more fully by shareholders. rather than } \\
\text { committing to pay long-term profits as interest to } \\
\text { debtholders }\end{array}$ & 0.73 & 0.89 & 0.67 & 0.86 & 0.88 & 0.68 & 0.71 & 0.83 & 0.56 & 0.51 & 0.73 & 0.45 & 0.70 & 1.40 & 0.64 & 1.24 \\
\hline (e) & $\begin{array}{l}\text { We expect our credit rating to improve. so we borrow } \\
\text { short-term until it does }\end{array}$ & 0.42 & 0.83 & 0.25 & $0.77^{* *}$ & 0.42 & 0.53 & 0.50 & 0.45 & 0.45 & 0.78 & 0.57 & 0.58 & 0.55 & 1.67 & 0.66 & 0.94 \\
\hline
\end{tabular}

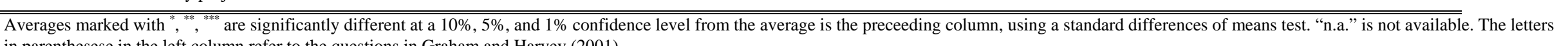

in parenthesese in the left column refer to the questions in Graham and Harvey (2001). 


\section{Publications in the Report Series Research* in Management}

\section{ERIM Research Program: "Finance and Accounting"}

\section{5}

Royal Ahold: A Failure Of Corporate Governance

Abe De Jong, Douglas V. Dejong, Gerard Mertens en Peter Roosenboom

ERS-2005-002-F\&A

http://hdl.handle.net/1765/1863

Capital Structure Policies in Europe: Survey Evidence

Dirk Brounen, Abe de Jong and Kees Koedijk

ERS-2005-005-F\&A

A Comparison of Single Factor Markov-Functional and Multi Factor Market Models Raoul Pietersz, Antoon A. J. Pelsser ERS-2005-008-F\&A

Efficient Rank Reduction of Correlation Matrices

Igor Grubišić and Raoul Pietersz

ERS-2005-009-F\&A

Generic Market Models

Raoul Pietersz and Marcel van Regenmortel

ERS-2005-010-F\&A

\footnotetext{
A complete overview of the ERIM Report Series Research in Management: https://ep.eur.nl/handle/1765/1

ERIM Research Programs:

LIS Business Processes, Logistics and Information Systems

ORG Organizing for Performance

MKT Marketing

F\&A Finance and Accounting

STR Strategy and Entrepreneurship
} 